WHOI $-81-51$

\section{ACOUSTIC ENVIRONMENT OF THE HATTERAS AND \\ NARES ABYSSAL PLAINS, WESTERN NORTH ATLANTIC OCEAN, DETERMINED FROM VELOCITIES AND \\ PHYSICAL PROPERTIES OF SEDIMENT CORES}

by

Brian E. Tucholke

WOODS HOLE OCEANOGRAPHIC INSTITUTION

Woods Hole, Massachusetts 02543

June 1981

TECHNICAL REPORT

Prepared for the Office of Navat. Research under Contracts N00014-75-C-0210 and N00014-79-C-0071; NR 083-0C4.

Reproduction in whole or in part is permitted for any purpose of the United States Govemment. In ci.ting this report in a bibliography, the reference given should be to: J.Acoust. Soc. Am. 68(5): 1376-1390 (November 1980).

Approved for public release; distribution unlimited.

Approved for Distribution: John I. Ewing, Chairman

Department of Geolocy and leophy'ics 


\title{
Acoustic environment of the Hatteras and Nares Abyssal Plains, western North Atlantic Ocean, determined from velocities and physical properties of sediment cores $^{\text {a) }}$
}

\author{
Brian E. Tucholke \\ Woods Hole Oceanographic Institution, Woods Hole, Massachusetts 02543 \\ (Received 12 February 1980; accepted for publication 13 August 1980)

\begin{abstract}
Seventeen piston cores up to $13 \mathrm{~m}$ long were recovered from representative acoustic and lithologic environments of the Hatteras and Nares Abyssal Plains in the western North Atlantic. Compressional-wave velocities (corrected to in situ conditions) and bulk physical properties measured on the cores are used to characterize the acoustic framework of these areas. For correlation with conventional seismic data, wholecore averages of properties are a better index to the acoustic nature of abyssal plain sediments than properties of the upper few centimeters of the seafloor because (1) strong changes in lithofacies (and acoustic properties) occur over depth scales of tens of centimeters to meters in the sediment column, and (2) conventional seismic frequencies of $3.5 \mathrm{kHz}$ or less sample these variations to subbottom depths of tens of meters and more. Wholecore properties are a function of the thickness and distribution of high-velocity silt and sand layers in the core; they vary in a complex fashion with proximity to the source of turbidity currents, distance from axial paths of turbidity-current flows, local and regional basin geometry, and seafloor slope. Thus strongly reflective seabed regions with numerous high-velocity layers are not restricted simply to near-source areas nor are weakly reflective seabed regions (clay sediments only) limited to "distal" areas. Whole-core properties show a good qualitative correlation to variations in $3.5-\mathrm{kHz}$ reflection profiles, and $3.5-\mathrm{kHz}$ echo character therefore provides a useful means of mapping general acoustic properties over large regions of abyssal plains.
\end{abstract}

PACS numbers: 43.30.Bp, 43.30.Dr, 92.10.Vz, 43.40.Ph

\section{INTRODUCTION}

Knowledge of compressional-wave velocities (hereafter called velocities) and bulk physical properties of marine sediments is important in interpretation of the geologic and geophysical framework of ocean basins. Only a few experimental studies on natural marine sediments were conducted prior to the $1960 \mathrm{~s}$, but they confirmed that general correlations exist between velocity and density, porosity, and grain size, and that surface-sediment velocities lower than bottom-water velocities were common (summarized by Nafe and Drake $^{1}$ ). Subsequently, the gross seabed velocity structure has been resolved in greater detail by wide-angle reflection studies..$^{2-4}$ However, such remote-sensing measurements still are limited by uncertainties in sound travel paths and velocity gradient, and they average over large volumes of sediment.

Direct sampling for both acoustic and physical properties has been accomplished by divers and from submersibles, ${ }^{5}$ but these measurements have been made mostly on seafloor surface samples and at shallow water depths. Laboratory analyses of a much broader spectrum of samples from the upper $30 \mathrm{~cm}$ of the Pacific Ocean seafloor have been reported by E. L. Hamilton, ${ }^{6-8}$ and these data form the basis for much of our present knowledge of the velocities and bulk properties of unconsolidated marine sediments. Hamilton ${ }^{8}$ also showed that for prediction of in situ properties, laboratory measurements of velocity should be corrected to in situ conditions by applying seawater/sediment velocity ratios at the appropriate temperatures. The applicability of this method was confirmed by Tucholke and Shirley ${ }^{9}$ in a study comparing in situ nose-cone veloci-

\footnotetext{
a) Contribution No. 4547 of Woods Hole Oceanographic Institution; Contribution No. 3048 of Lamont-Doherty Geological Observatory.
}

meter measurements of piston cores with laboratory velocities corrected to in situ conditions. Similar corrections of laboratory porosity and density measurements to in situ conditions normally are insignificant, or they are so small that they are within the errors of measurement and can be ignored in practical applications. $^{8}$

The most successful characterization of sediments to depths of 10-20 m below the seafloor has been by analysis of samples recovered in gravity cores and piston cores. In the equatorial Pacific, Embley ${ }^{10}$ and Embley and Johnson ${ }^{11}$ measured bulk properties and velocities in piston cores and correlated the results with reflector sequences in $3.5-\mathrm{kHz}$ seismic profiles. More detailed studies of pelagic carbonates in the Pacific by Mayer ${ }^{12}$ showed that strong correlations exist between velocity and mean grain size and that diagenesis in carbonates has a significant effect on physical properties.

In the western North Atlantic Ocean, velocity and physical-property measurements have been made on piston cores that recovered a variety of lithofacies including hemipelagic clays, turbidites, and calcareous oozes and marls. ${ }^{13-15}$ In these studies sound velocities were measured at, or corrected to, temperatures of $20^{\circ}$ to $23^{\circ} \mathrm{C}$; thus they must be recalculated to obtain in situ velocities. The velocity measurements were made through both the sediment core and a core liner, and uncertainty therefore exists about potential measurement errors introduced by variation in liner thickness or by voids between the core and the liner. These measurements also were made parallel to bedding planes in the cores; although there probably is little velocity anisotropy in visually uniform clays within the upper few tens of meters below the seafloor ${ }^{9}$ there may be significant anisotropy in well-bedded sediments such as turbidites. Preferred grain orientation is common in turbidite beds,$^{16.17}$ and this orientation can cause 
velocity anisotropy. ${ }^{6,18}$ Thus velocity measurements made parallel to the beds on such samples may not be representative of normal-incidence sound transmission.

In 1976 we began a program of velocity and physicalproperty measurements on piston cores recovered from varied acoustic and morphologic provinces in the western North Atlantic. There were two primary objectives: (1) To determine quantitatively the sedimentary velocities representative of in situ, normal-incidence sound transmission and the relation of these velocities to physical properties of the sediments, and (2) to relate qualitatively these measured parameters to the acoustic character of the sedimentary column as recorded in $3.5-\mathrm{kHz}$ (and, to a limited extent, $12-\mathrm{kHz}$ ) profiles. During the program, more than 3600 measurements of both velocity and bulk properties have been obtained on 64 cores from the western North Atlantic.

This report presents a subset of results obtained on seventeen piston cores from the Hatteras Abyssal Plain and the Nares Abyssal Plain. These cores comprise a transect of turbiditic sediments extending from a "proximal" depositional location in the north central Hatteras Abyssal Plain to the most "distal" portions of the Nares Abyssal Plain. These data are used to illustrate the probable range of in situ acoustic and physical properties characteristic of abyssal plain sediments in the western North Atlantic. Although the number of cores is limited, they adequately sample most of the variations observed in echo character on the abyssal plains; it therefore is possible to use the more widely distributed $3.5-\mathrm{kHz}$ profiles to predict sediment acoustic and physical properties of the abyssal plains on a regional basis.

\section{METHODS}

All piston cores were obtained using a standard Ewing piston corer with a 1200-1b. corehead. Once recovered, the unlinered cores were extruded and wrapped to prevent moisture loss while they equilibrated with laboratory temperatures (normally $2-4$ hours). Velocity was measured perpendicular to the bedding at intervals of $20 \mathrm{~cm}$ or less along the length of each core, and the sediment temperature at each measurement location was recorded.

The velocimeter consists of two probes $3 \mathrm{~mm}$ thick and $27 \mathrm{~mm}$ wide, rigidly fixed $5 \mathrm{~cm}$ apart, that are attached to a drill-press stand and inserted into the center of the unsplit core. Each probe contains a transducer resonant at $200 \mathrm{kHz}$; the pulse delay between probes is proportional to the velocity of the medium being measured and is read from an attached dual-trace oscilloscope. The velocimeter is calibrated (and periodically checked during core measurement) in distilled water at varying temperatures. Accuracy of measurements is $\pm 3 \mathrm{~m} / \mathrm{s}$. Because of the fixed $5-\mathrm{cm}$ probe spacing, velocity measurements across highvelocity beds thinner than $5 \mathrm{~cm}$ will be minimum values.

All laboratory velocities were corrected to in situ conditions using the method outlined by Hamilton ${ }^{6}$ and tables for the speed of sound in seawater. ${ }^{19}$ The values also were corrected for a down-core thermal gradient of $0.06{ }^{\circ} \mathrm{C} / \mathrm{m}$ which is an average value for the areas of interest. ${ }^{20}$

Sediment-bulk properties were determined on 8-10 $\mathrm{cm}^{3}$ sy ringe samples obtained at the same time and in the same locations as the velocity measurements. These samples were capped, sealed with wax, and refrigerated until they could be processed in the shore laboratory. Shore-lab. determinations were made for wetbulk density, water content, porosity, void ratio, and grain density. Corrections for pore-water salinity of $35 \%$ were applied to all samples.

The $3.5-\mathrm{kHz}$ profiles used for comparison with sediment properties are analog profiles recorded under a variety of weather and instrumental conditions, and we emphasize that the comparison of echo character and sediment properties is strictly qualitative. However, certain useful and previously undocumented correlations do exist, as discussed at the end of this paper.

\section{GEOLOGIC SETTING}

The Hatteras Abyssal Plain lies between the Bermuda Rise and the lower continental rise off the eastern U. S. and it extends southward from near the latitude of Cape Hatteras some $1250 \mathrm{~km}$ to the Caicos and Greater Antilles Outer Ridges (Fig. 1). Its depth ranges from 5200 to $5500 \mathrm{~m}$, with a southward slope of about $1: 6000$. Primary source area for the turbidities are the Hatteras, Wilmington, and Hudson Canyon fan-systems traversing the continental rise along the northwest part of the abyssal plain. ${ }^{21,22}$

Turbidity currents reaching the southern part of the abyssal plain from Providence Channel via Cat Gap probably are of minor importance. The near-source areas off the northern canyons generally contain the coarsest, sand-size debris with interbedded silts and clays, and the southern part of the plain contains only interbedded silts and clays.

At the southeast corner of the Hatteras Abyssal Plain, Vema Gap provides a deep (5600-5800 m) passage allowing turbidity currents to flow eastward onto the Nares Abyssal Plain. The Nares Abyssal Plain is elongated east-west and is about $800 \mathrm{~km}$ long and from $200-400 \mathrm{~km}$ wide. Its depth ranges from 5800 to nearly $6000 \mathrm{~m}$ with an eastward sloping seafloor having a gradient of about $1: 4000$. Because the only major source of turbidity currents is distal flows from the Hatteras Abyssal Plain entering through Vema Gap, theturbidites on the Nares Abyssal Plain contain only silt and finergrained sediment. Silt beds are thickest near the western end of the plain, and they become both thinner and more numerous toward the east until they represent mere silt partings in otherwise clay-size turbidites. At the easternmost end of the plain, such slit partings are rarely recognized.

At the northeast corner of the Nares Abyssal Plain, the distal margin of the plain connects to two major fracture-zone valleys, the Kane (or Nares) Fracture Valley and the Nares Deep Fracture Valley (Fig. 1). Myriad abyssal gaps through the rough abyssal hill 


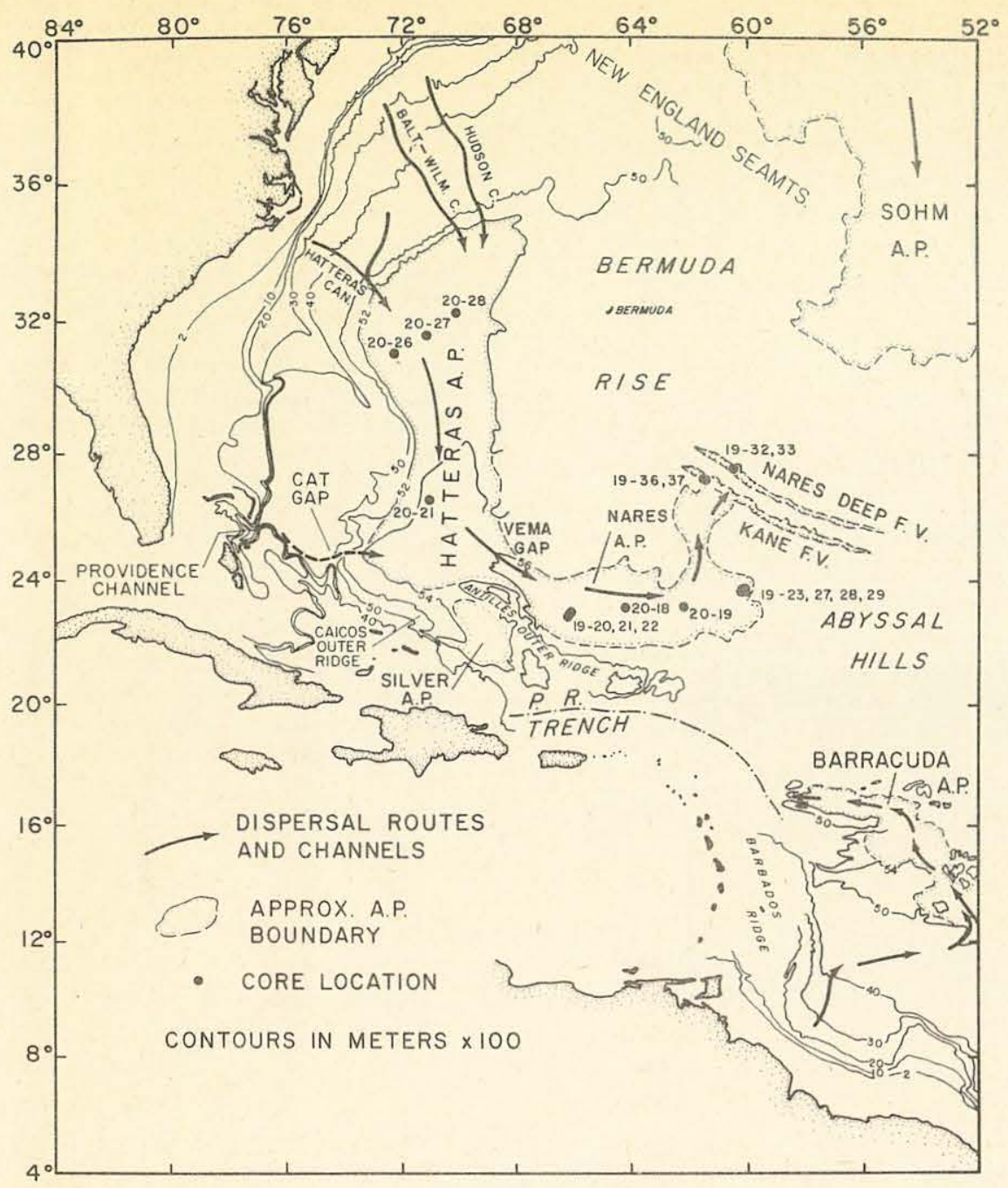

FIG. 1. Locations of abyssal-plain cores measured in this study. Arrows show major dispersal paths of turbidity currents. topography probably connect both the $6150 \mathrm{~m}$-deep Kane Fracture Valley and the more northerly, $6400 \mathrm{~m}$-deep Nares Deep Fracture Valley to the Nares Abyssal Plain. ${ }^{23}$ The flat-lying sediments in the Kane Fracture Valley contain numerous thin silt beds and laminae, but only turbiditic and pelagic clays are found to the north in the flat-floored Nares Deep Fracture Valley.

\section{RESULTS}

\section{A. Introduction}

Seventeen cores from ten locations define the major variations in velocities and physical properties of sediments from the Hatteras and Nares Abyssal Plains (Fig. 1). Although only one core was obtained at some locations, lateral variations in $3.5-\mathrm{kHz}$ echo character occur slowly in the sampled regions, and the properties of any one core are considered generally representative for an area within a radius of several tens of kilometers. This supposition has been tested and confirmed by Tucholke and Shirley ${ }^{9}$ for cores from the Nares Abyssal Plain and Greater Antilles Outer Ridge, and it also is confirmed by our multiple sampling at several of the locations in this study. Such core-to-core comparison also shows that among the cores studied there is no differential coring disturbance from one core to another; if coring disturbance exists, it is megascopically undetected and uniform in each core.

\section{B. Velocity-general observations}

Although grain-size analyses were not performed on our cores, it is clear from the visual core descriptions alone that compressional-wave velocities are closely related to the mean grain size of the beds sampled (Figs. 2-11). Such a direct relation has been demonstrated empirically in previous studies by Horn et al ${ }^{24}$ and Hamilton. ${ }^{6}$ Velocities in clay-size sediments typically are $1510-1530 \mathrm{~m} / \mathrm{s}$; in silts, $1600-1700 \mathrm{~m} / \mathrm{s}$; and in sands, up to $1850 \mathrm{~m} / \mathrm{s}$.

In those instances where the sampling interval was small enough, grain-size grading in individual turbidite beds also is reflected by a gradation in velocity values (e.g. Fig. 3). This grading in velocity forms high-velocity "tails" on frequency histograms of velocity distribution in the cores (Fig. 12). There is a slight bimodal distribution of velocity in some cores that may reflect a fairly distinct break between grain-size modes in the turbidites. Such quasibimodal distribution in grain size has been observed in other cores from the Hatteras Abyssal Plain.14,21 

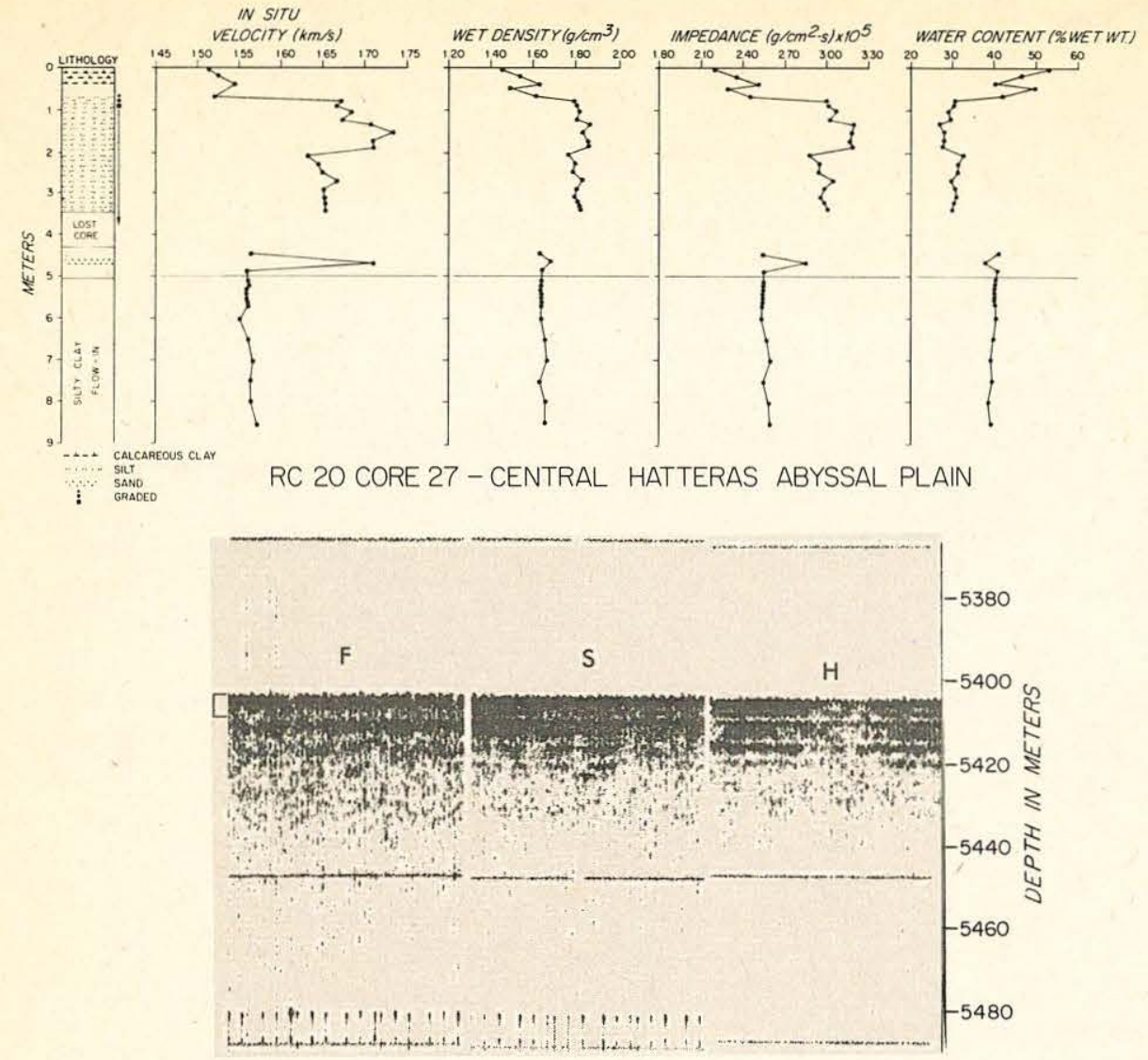

FIG. 2. Above: Lithology and properties of core RC20-27 from the strongly reflective seabed of the north central Hatteras Abyssal Plain; explanation in Fig. 4. Below: $3.5-\mathrm{kHz}$ reflection profiles recorded with $3-\mathrm{ms}$ pulse length at and near the coring site; $5-\mathrm{m}$ penetration of good-quality core (based on measured sediment velocities) is shown by bracket at left. $F=$ record at full ahead (9 kts), $S=$ record at slow ahead ( $2 \mathrm{kts}$ ), $H=$ record hove to on coring station. Depth scale at right based on water velocity. Similar figures that follow progress to areas of more weakly reflective seabed.

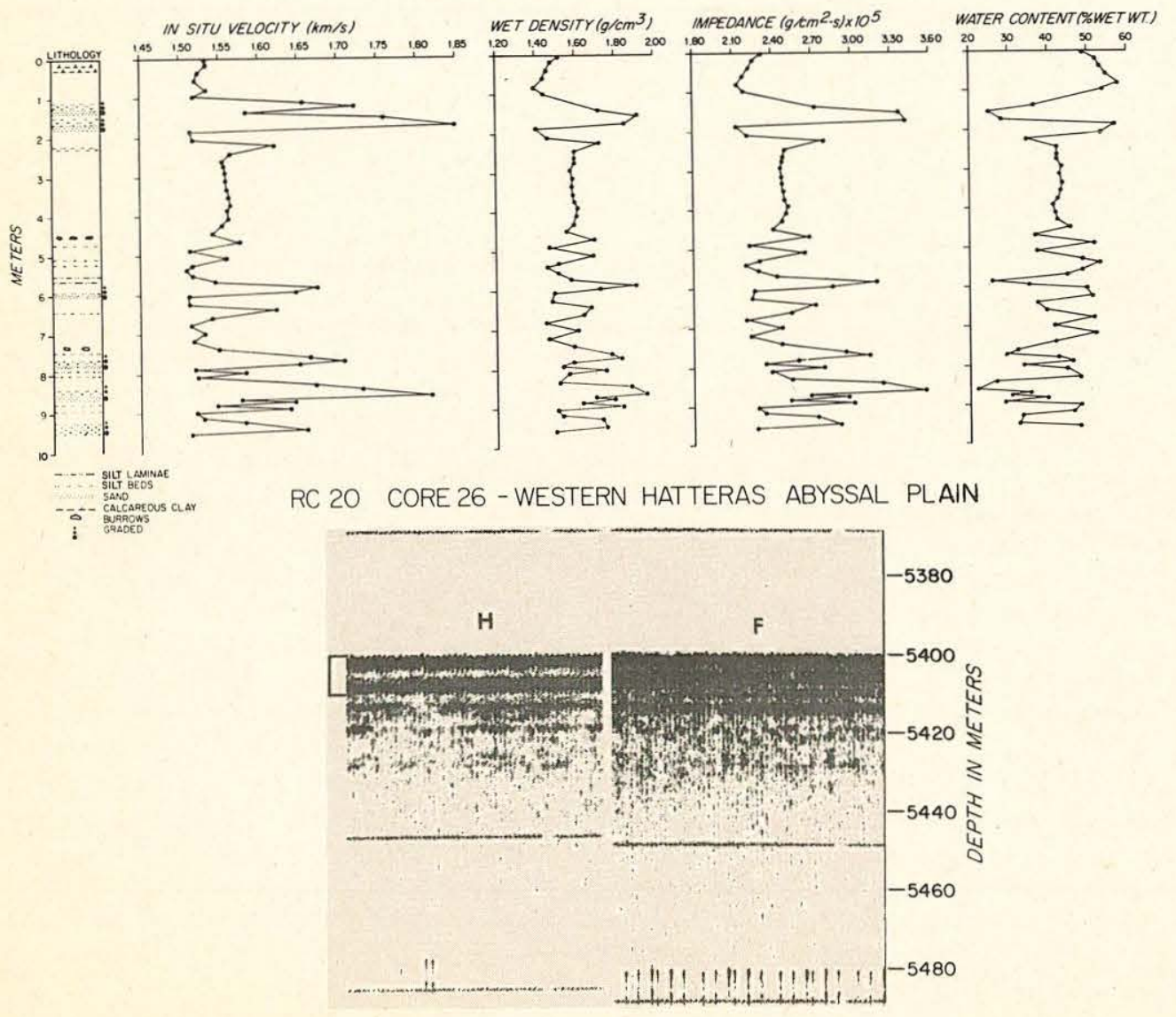

FIG. 3, Core RC20-26, western Hatteras Abyssal Plain; explanation in Figs. 2 and 4. Note increased recording gain in profile at right does not significantly improve signal penetration. Core penetration indicated at upper left. 


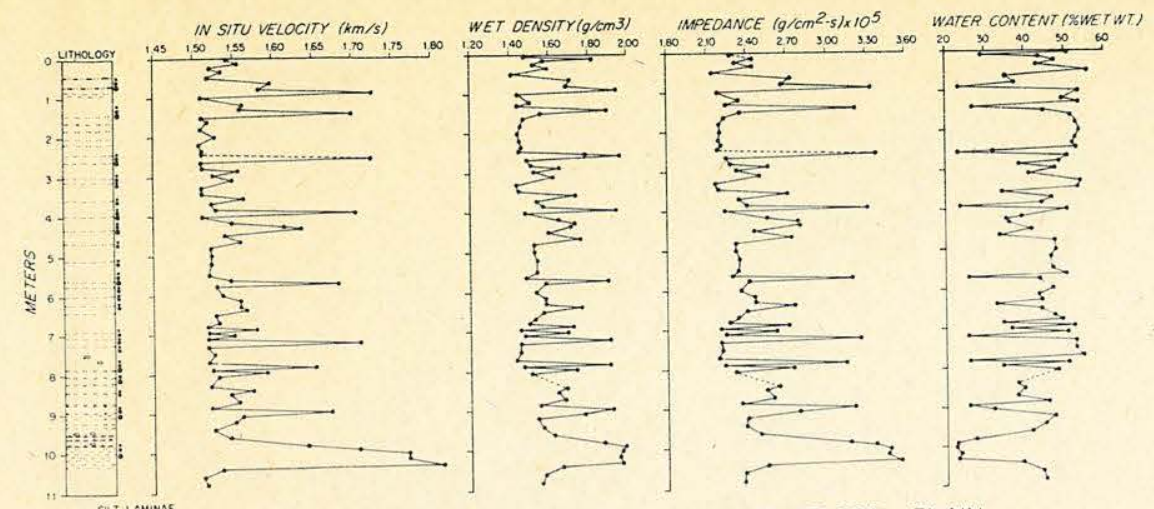

RC 20 CORE 21-SOUTHERN HATTERAS ABYSSAL PLAIN

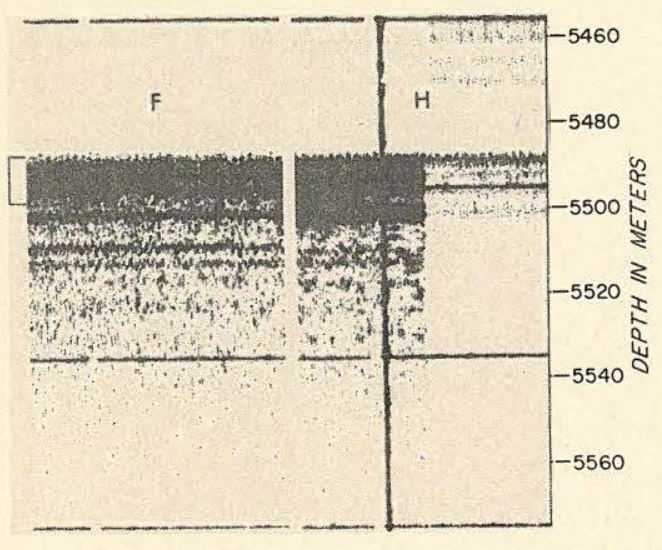

FIG. 4. Above: Lithology and properties of core RC20-21 from southern Hatteras Abyssal Plain. Unpatterned areas in lithology column are clay and silty clay; other lithofacies as indicated. In plots, dashed lines show where a velocity measurement was made with no corresponding bulk property measurement (and vice versa); $x$ 's in subsequent plots indicate the two measurements were at slightly different depths (but within $3 \mathrm{~cm}$ ). Below: $3.5-\mathrm{kHz}$ reflection profiles at the coring site; explanation in Fig. 2. Right half of " $H$ " profile recorded with $1-\mathrm{ms}$ pulse length.
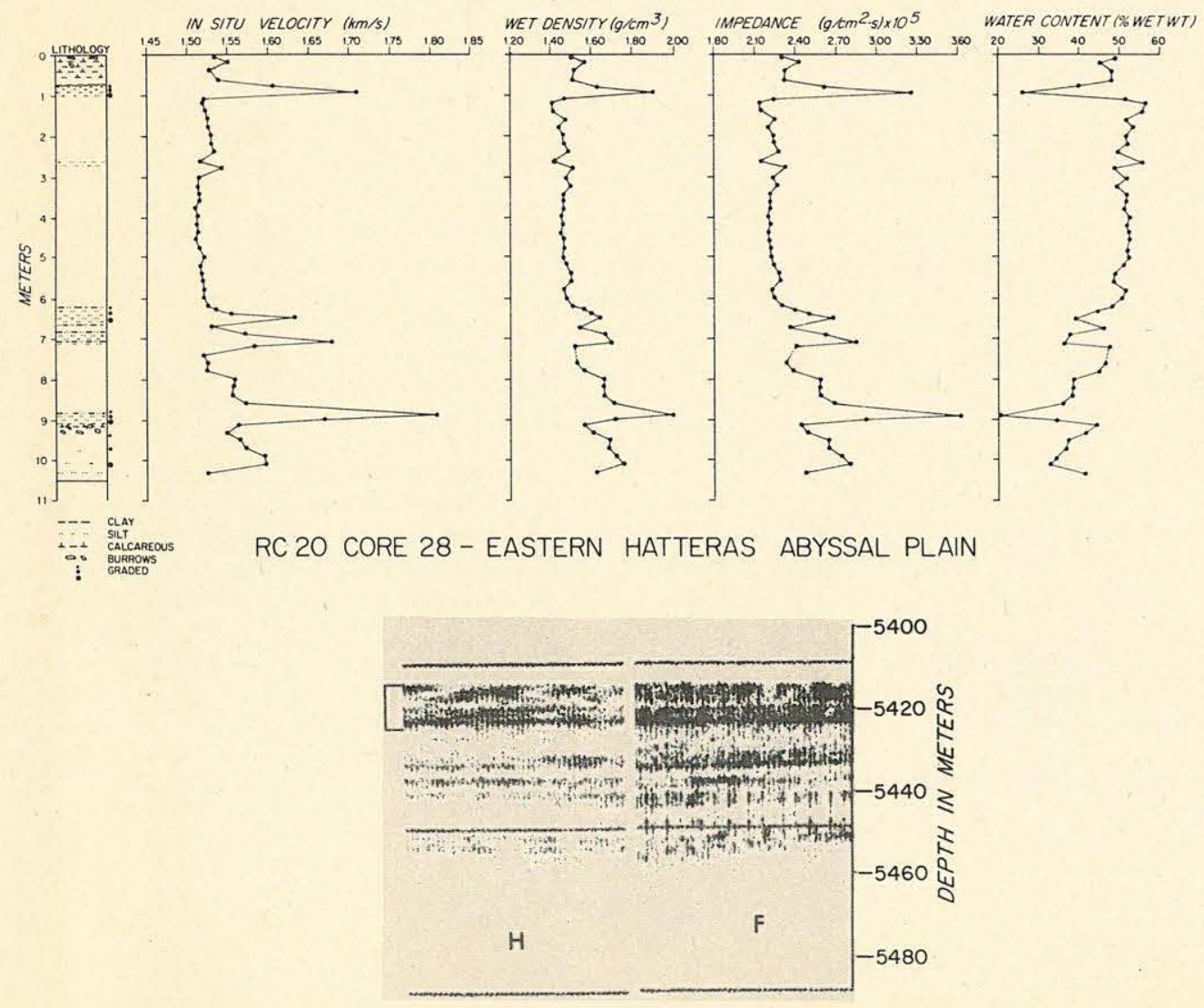

FIG. 5. Core RC20-28

from northeastern Hatteras Abyssal Plain; explanation in Figs. 2 and 4. 

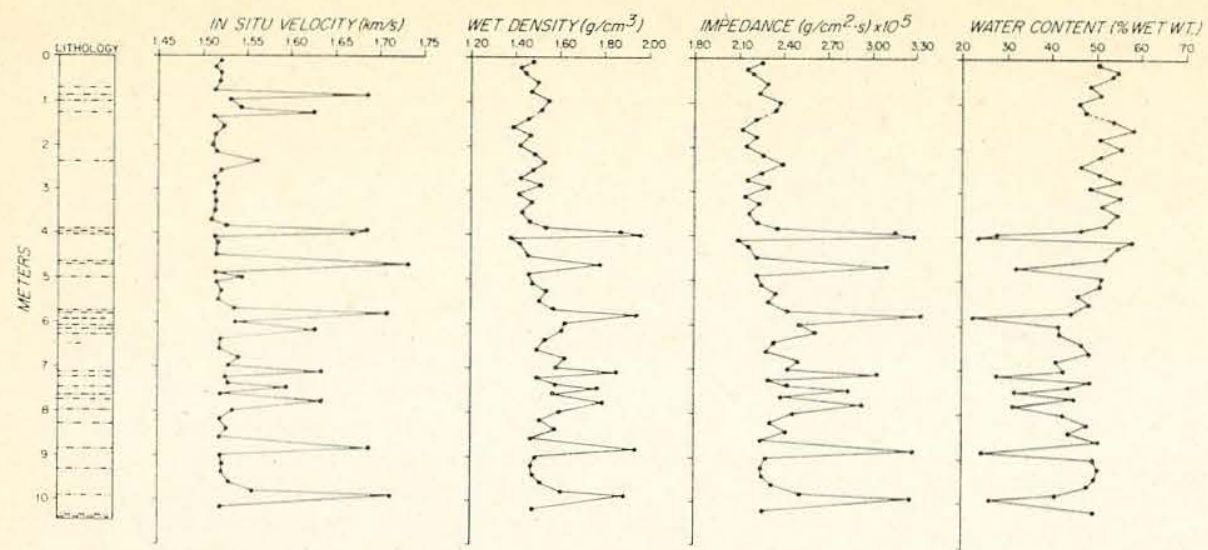

- - SIT BeOS a LaMrar

RC 20 CORE 18 - NARES ABYSSAL PLAIN
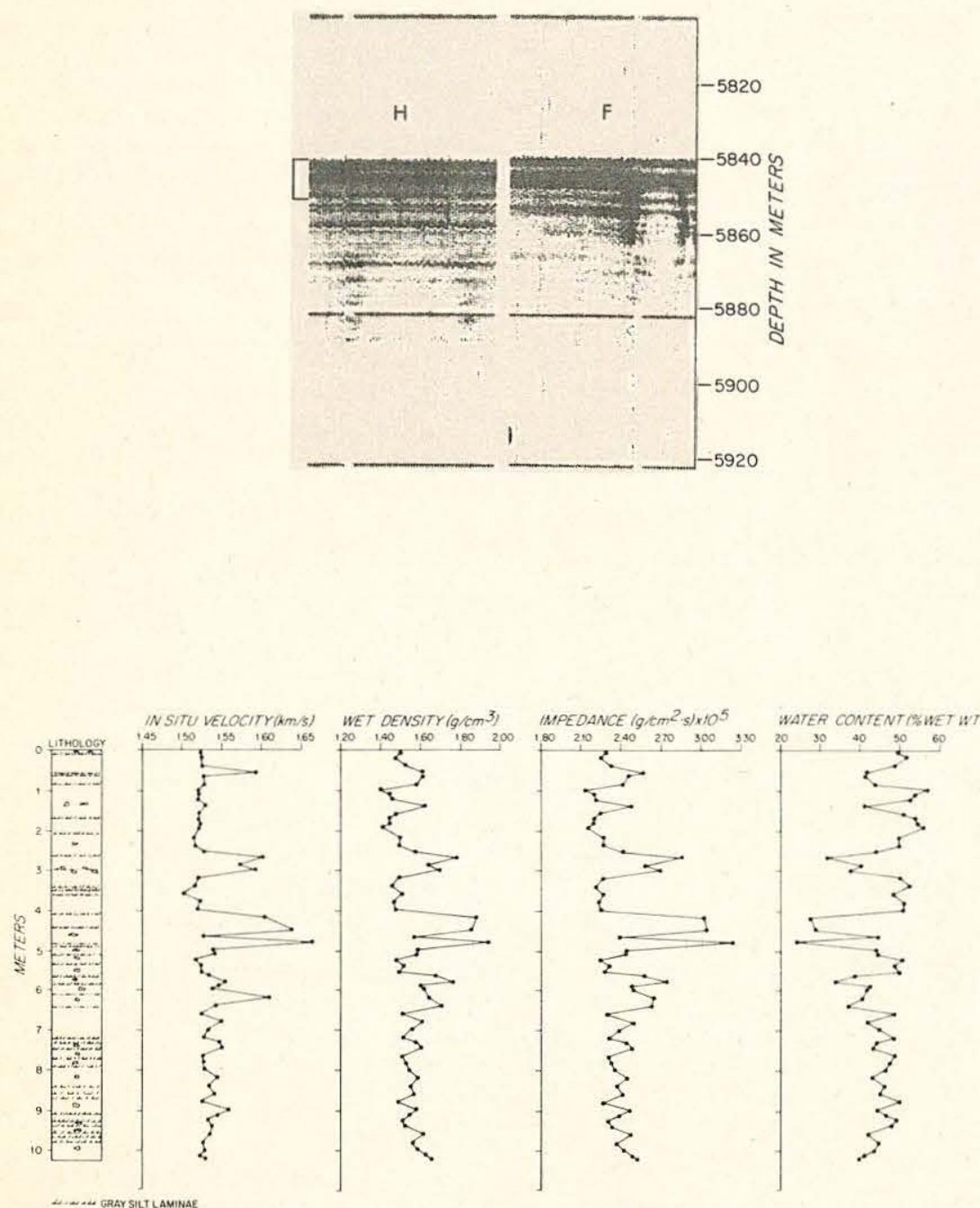

- BhOMN SIT

RC 20 CORE 19 - NARES ABYSSAL PLAIN

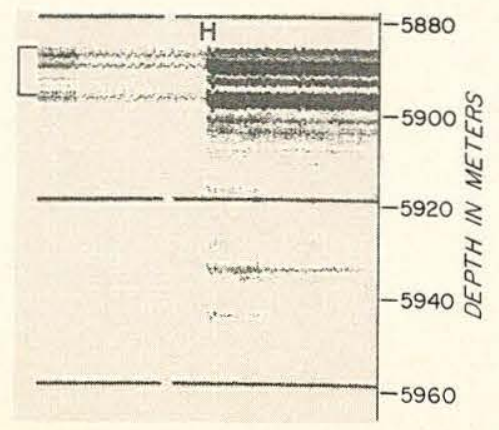

FIG. 6. Core RC20-18, west central Nares Abyssal Plain; explanation in Figs. 2 and 4 . Note focusing of subbottom returns, possibly caused by surficial channels that control turbidite dispersal.
FIG. 7. Core RC20-19, east central Nares Abyssal Plain; explanation in Figs. 2 and 4 . Left portion of $3.5-\mathrm{kHz}$ profile recorded with $1-\mathrm{ms}$ pulse length. 


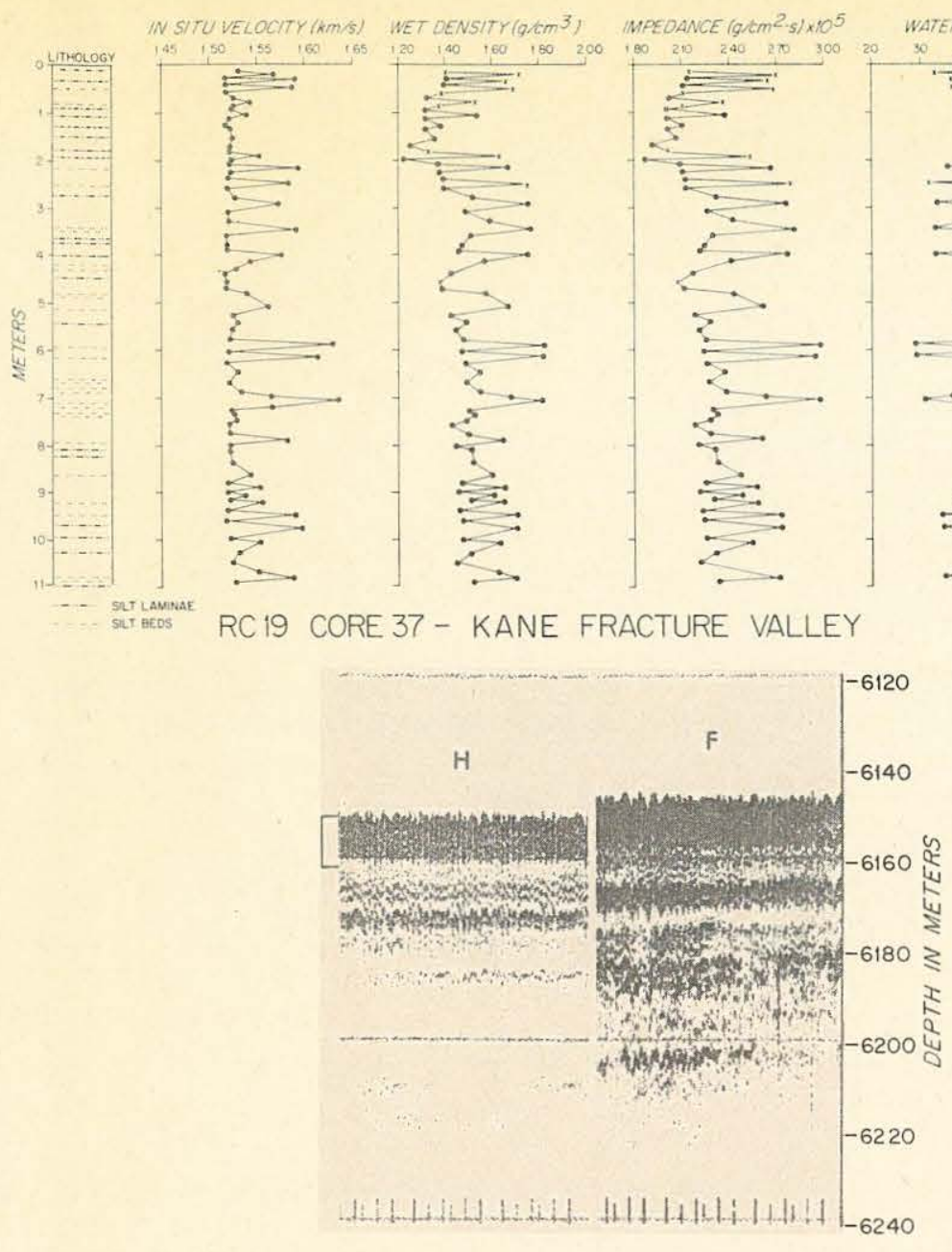

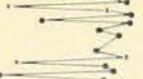

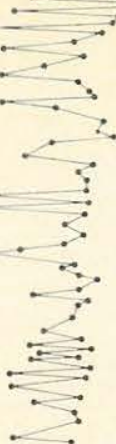

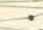<smiles></smiles>

FIG. 8. Core RC19-37, Kane Fracture Valley; explanation in Figs. 2 and 4 . Lower recording gain was used for the $3.5-\mathrm{kHz}$ reflection profile at left.
Calcareous beds (marls) are uncommon in the cores, but in the few marls that are present there is no consistent correlation between velocity and carbonate content; the same lack of correlation appears in numerous marly layers in other cores that we have recovered from shallower depths, in agreement with previous empirical studies..$^{624}$ The principal control on velocity in the calcareous beds probably is mean grain size; thus claysize and fine silt-size nannoplankton marls have relatively low velocities, and velocity peaks occur when silt and sand-size foraminifera are abundant.

\section{Velocity versus density}

As determined in previous studies ${ }^{6,24}$ there is a general increase in velocity with increase in wet bulk density (Fig. 13). At densities below about $1.5 \mathrm{~g} / \mathrm{cm}^{3}$, velocity is nearly constant at $1520 \pm 13 \mathrm{~m} / \mathrm{s}$, although it may increase slightly at the lowest densities. The range of velocities at densities less than $1.5 \mathrm{~g} / \mathrm{cm}^{3}$ is considerably smaller than that determined in previous studies. Compared to plots by Horn et al. ${ }^{14}$ the scatter is reduced by nearly 50\%. At higher densities (that is, where silt and sand beds were measured) the scatter in velocities is only slightly less than that in previous work. Part of the observed scatter may be due to the fact that some velocity measurements were made on silt beds thinner than the velocimeter probe spacing, thus giving only minimum velocity values; in addition, some silt beds also were thinner than the size of the bulk-property sampling syringe, so that lower (i.e., clay-type) densities may result. However, these uncertainties normally are paired on a given sample and they shift the data point along the density-velocity trend so that their scatter-producing effect is minimized.

The tighter distribution of sample points in the velocity-density plot of Fig. 13 as compared with previous studies results partly from the fact that our data are from only one morphologic province (abyssal plains), whereas Horn et al. ${ }^{14}$ lumped their abyssal-plain samples with data from surrounding environments. Hamilton $^{6}$ has demonstrated that in the Pacific basin significant differences exist between such data groupings for abyssal plain, abyssal hill, and continental terrace environments. Despite the improvements in velocitydensity correlation shown in Fig. 13, enough scatter still exists that one parameter cannot be used to predict the other with the accuracy normally required in ocean acoustics work. Approximations of in-situ velocity can be derived from wet density, but mean grain size probably remains the better predictor. ${ }^{6}$

\section{Velocity versus porosity}

Velocity and porosity exhibit the same inverse relationship previously demonstrated by other investigators 


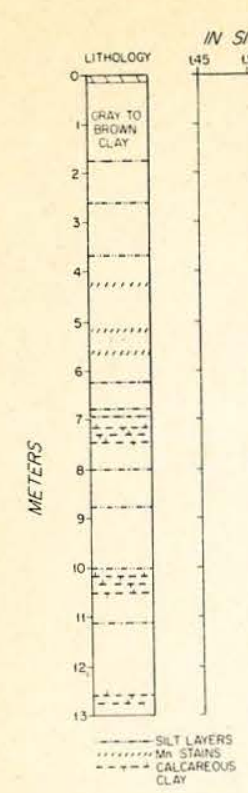

IN SITU VELOCITY $(\mathrm{km} / \mathrm{s})$

WET OENSITY $\left(\mathrm{g} / \mathrm{cm}^{3}\right)$ IMPEOANCE $\left(\mathrm{g} / \mathrm{cm}^{2}-s\right) \times 10^{5}$ WATER CONTENT (\%WETWT)

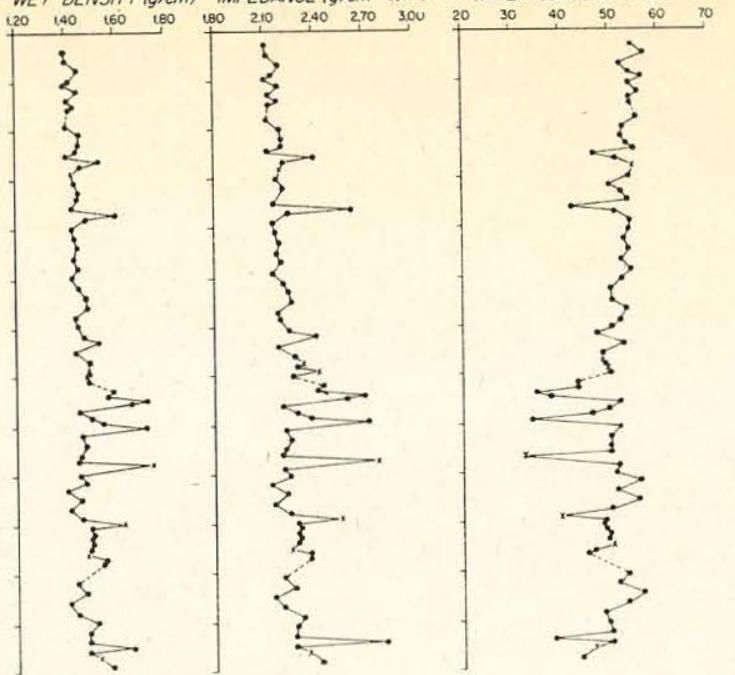

RC19 CORE 20 - NARES ABYSSAL PLAIN

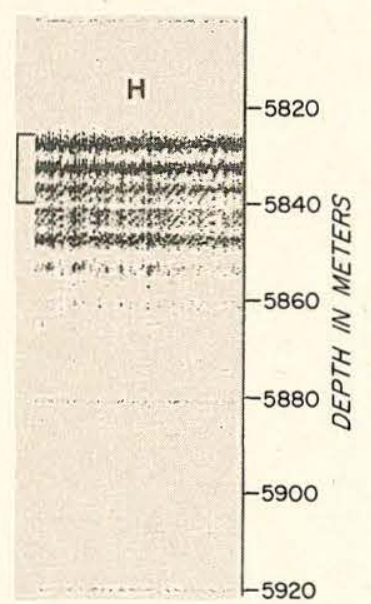

FIG. 9. Core RC19-20, western Nares Abyssal Plain; explanation in Figs. 2 and 4.

(Fig. 14). The relation also is approximately the inverse of the velocity/density relation, modified only by the generally small effects introduced by variations in grain density. Like the plot of velocity versus density, the scatter is minimized because the data are restricted to abyssal-plain samples. Porosity may be a slightly better predictor of $i n$-situ velocity than is wet bulk density (Figs. 13 and 14).

\section{E. Density $\times(\text { velocity })^{2}$}

The product of density times the square of velocity is an important term in equations relating constants in elastic or viscoelastic media ${ }^{7,8,25}$ :

$$
\begin{aligned}
& \text { Lame's constant } \lambda=\left(3 k-\rho V_{p}^{2}\right) / 2, \\
& \text { Poisson's ratio } \sigma=\left(3 k-\rho V_{p}^{2}\right) /\left(3 k+\rho V_{p}^{2}\right), \\
& \text { Rigidity (shear) modulus } \mu=\frac{3}{4}\left(\rho V_{p}^{2}-k\right), \\
& \text { Velocity of shear wave } V_{s}=(\mu / \rho)^{1 / 2}=\left[\frac{3}{4}\left(V_{p}^{2}-k / \rho\right)\right]^{1 / 2},
\end{aligned}
$$

where $k=$ bulk modulus of the water-mineral system. Hamilton ${ }^{8}$ demonstrated that most naturally occurring unconsolidated marine sediments have a small but significant rigidity $(\mu)$ and that the Wood equation, ${ }^{26}$ which does not include rigidity, is inappropriate to apply to most marine sediments.

The values of $\rho V_{p}^{2}$ determined for sediments of western North Atlantic abyssal plains show very strong correlation with porosity (Fig. 15), as was similarly demonstrated for Pacific sediments by Hamilton. ${ }^{6}$ Porosity therefore provides a useful index to $\rho V_{p}^{2}$ that allows calculation of other constants [Eqs. (1-4)] in the absence of compressional-wave velocity measurements.

A significant deviation from this correlation occurs in a number of samples from the most "distal" abyssal plain cores (bold symbols, Fig. 15). All of these samples are clay-size sediment of low grain density $(\leqslant 2.50$ $\mathrm{g} / \mathrm{cm}^{3}$ ) that probably have been preferentially transported to these "distal" locations because of their low density. It is likely that these samples contain large quantities of montmorillonite and that the low grain densities result from water adsorbed in the crystalline lattice. Such expansion of the montmorillonite lattice should produce bulk samples of lower porosity and lower wet-bulk density, shifting sample points as observed in Fig. 15. Thus, in "distal" abyssal plain environments, porosity may not always be a reliable index to $\rho V_{p}^{2}$. It also should be noted that Tucholke and Shirley ${ }^{9}$ deter- 


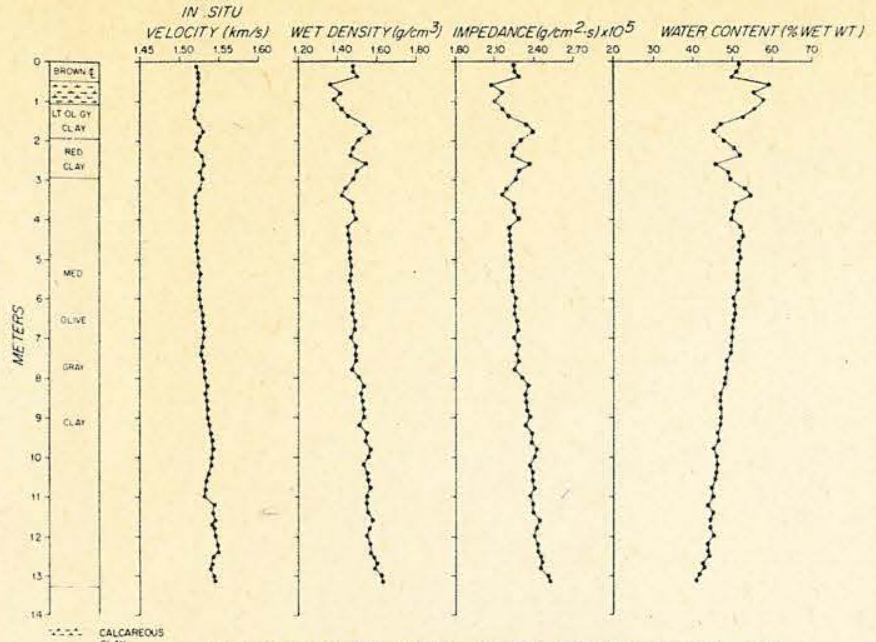

RC 19 CORE 33-NARES DEEP FRACTURE VALLEY

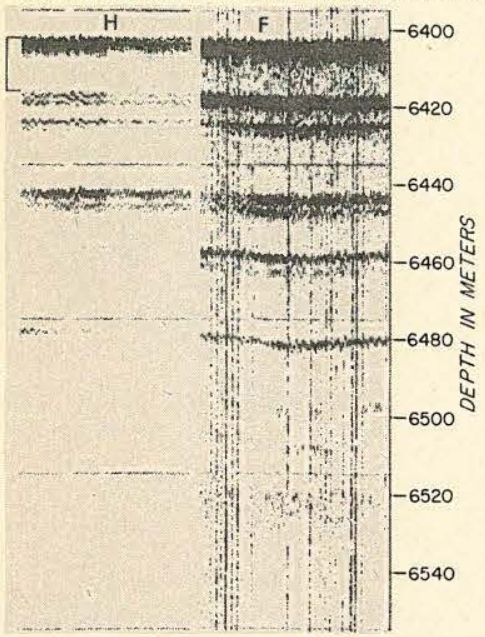

FIG. 10. Core RC19-33, Nares Deep Fracture Valley; explanation in Figs. 2 and 4. Lower recording gain was used for $3.5-\mathrm{kHz}$ reflection profile at left.

mined that laboratory measurements of $V_{p}$ corrected to $i$-situ conditions are about one percent lower than in-situ values for piston cores from the Nares Abyssal Plain. They attributed this difference to reduction in the frame bulk modulus, $k_{f}$, and/or the rigidity (shear) modulus, $\mu$, due to visually undetected disturbance during the coring process. The potential effect of this velocity reduction therefore should be recognized in any calculations.

The in-situ system bulk modulus, $k$, in Eqs. (1)-(4) is dependent on the aggregate bulk modulus of mineral grains $\left(k_{s}\right)$, the bulk modulus of pore water $\left(k_{w}\right)$, the "frame" or "skeletal" bulk modulus $\left(k_{f}\right)$, and the fractional porosity $(n)$ as shown in Gassmann' $\mathrm{s}^{25}$ equations:

$$
k=k_{s} \frac{k_{f}+Q}{k_{s}+Q}, \quad Q=\frac{k_{w}\left(k_{s}-k_{f}\right)}{n\left(k_{s}-k_{w}\right)} .
$$

Each of the component bulk moduli can be calculated and derived from empirical data reported here and by Hamilton ${ }^{7}$ as outlined in Hamilton's paper.

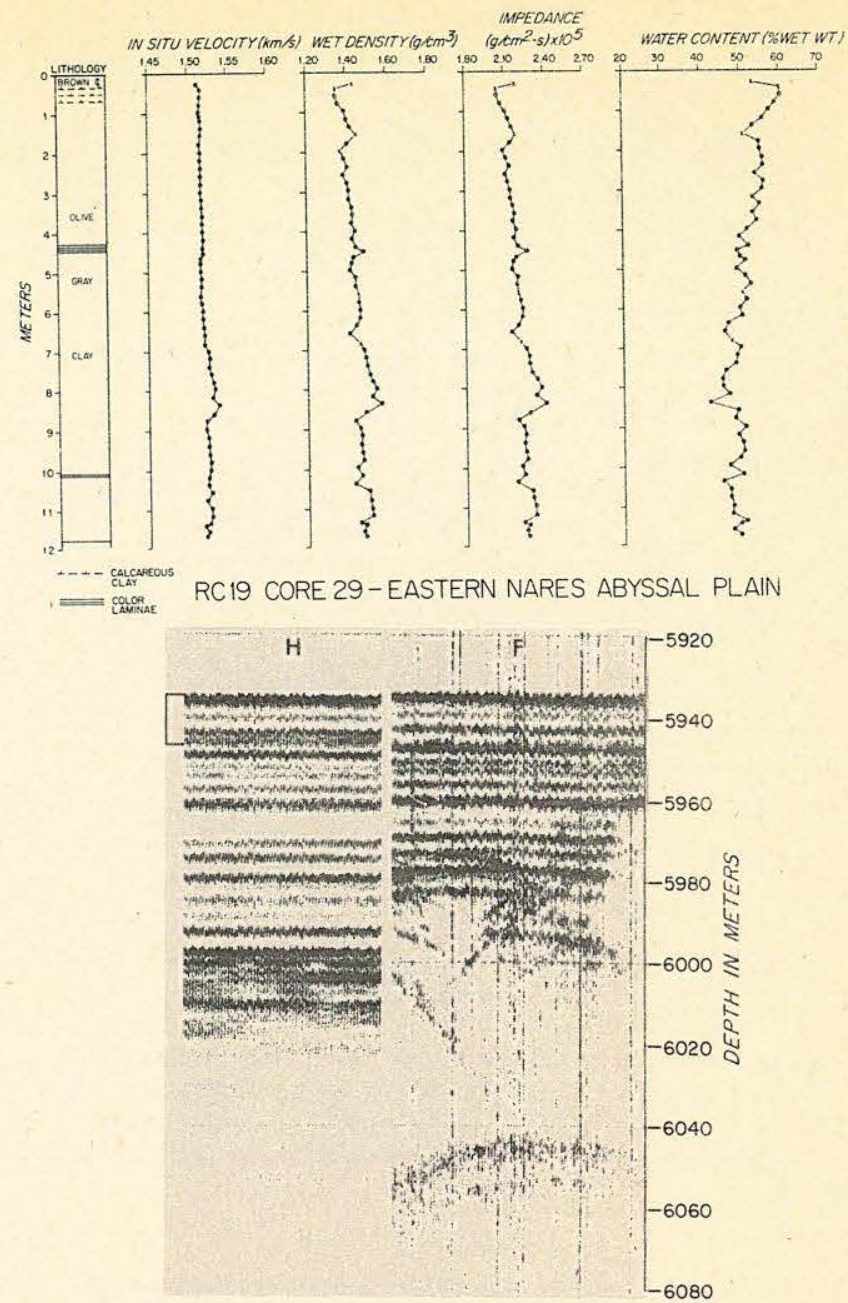

FIG. 11. Core RC19-29, eastern Nares Abyssal Plain; explanation in Figs. 2 and 4 . Hyperbolic echoes at lower right near 5980-6000 m probably originate from disruptions at contact between laminated turbidites and nonreflective pelagic sediments; both overlie "basement" at $6050^{+} \mathrm{m}$.

\section{F. Environmental distribution of properties}

\section{Introduction}

Interaction of an acoustic signal with the ocean bottom normally occurs over a large area, and the signal response is an average over both this area and over some frequency-dependent depth into the sedimentary layers. Therefore, over most geophysically useful frequencies (a few hertz to a few kilohertz) where significant signal penetration into the sediment column occurs, vertical inhomogeneities in the sedimentary layers play a significant role. Because of these inhomogeneities, "seafloor" acoustic character (within a few tens of centimeters of the ocean bottom) may differ significantly from "seabed" character (tens of meters or more into the ocean bottom). "Seafloor" acoustic character is important at frequencies of tens of $\mathrm{kHz}$ where signal penetration is minimal, but at the conventional $3.5-\mathrm{kHz}$ (or $12-\mathrm{kHz}$ ) frequencies considered in this and similar studies, signal penetration normally is tens of meters or more and "seabed" acoustic character becomes important. Both sets of characteristics are considered in the discussion below. 


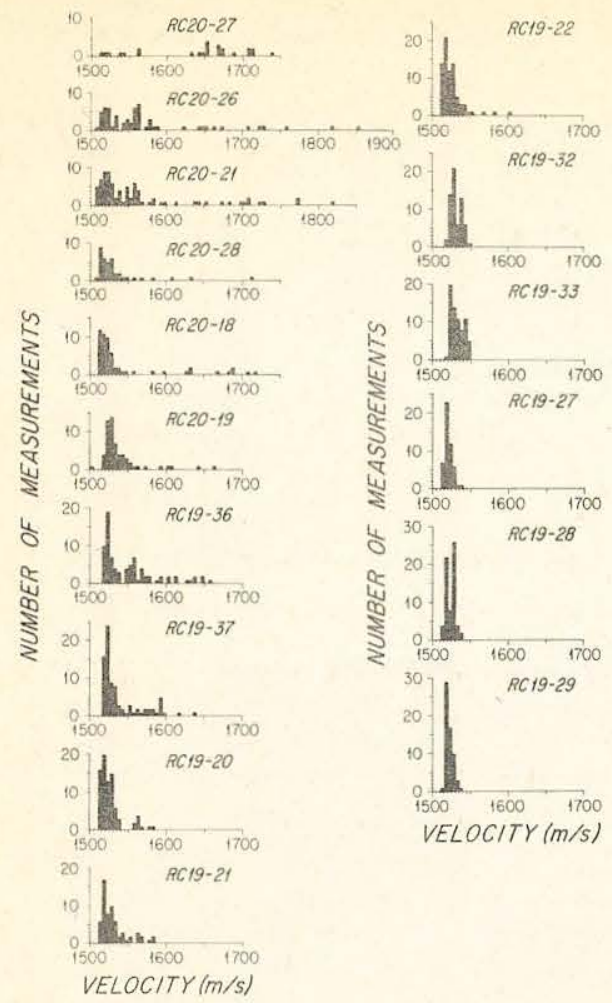

FIG. 12. Distribution of measured velocities (corrected to insitu) in piston cores from the Hatteras and Nares Abyssal Plains. Arranged from strongly reflective seabed (upper left) to weakly reflective seabed (lower right) environments (see Table I).

\section{2. "Seabed" acoustic character (whole-core analyses)}

"Seabed" acoustic character can be reasonably approximated by using whole-core averages of properties measured to depths of $10-12 \mathrm{~m}$ into the seabed.

Arranging the cores in a gradational sequence based on whole-core properties (Table I) shows that these properties do not vary simply as distance from the mouth of the source canyon ("proximal" to "distal"), nor do they vary directly with distance from the axial flow path of turbidity currents onto the abyssal plain (i.e., with "dynamic regime"). Instead, the whole-core properties are primarily a function of the vertical distribution of high-velocity (i.e., coarse) beds which is determined both by the above parameters and by local and regional basin geometry. The whole-core properties of sediments with a few thick sand beds are very similar to those of sediments with numerous thinner silt beds. The acoustic environment of two such sedimentary provinces will be similar even though deposition was under markedly different dynamic regimes and in much different proximity to source. In this report, wholecore properties that are determined largely by the presence of coarser, high-velocity beds are considered representative of regions of strongly reflective seabed; this is in contrast to fine-grained, low-velocity, and low-density sediments that are typical of weakly reflective seabed environments.

The gradational sequence of whole-core properties in Table I can be subdivided into four groups. The first group of cores, RC20-27 and RC 20-26 from the northern

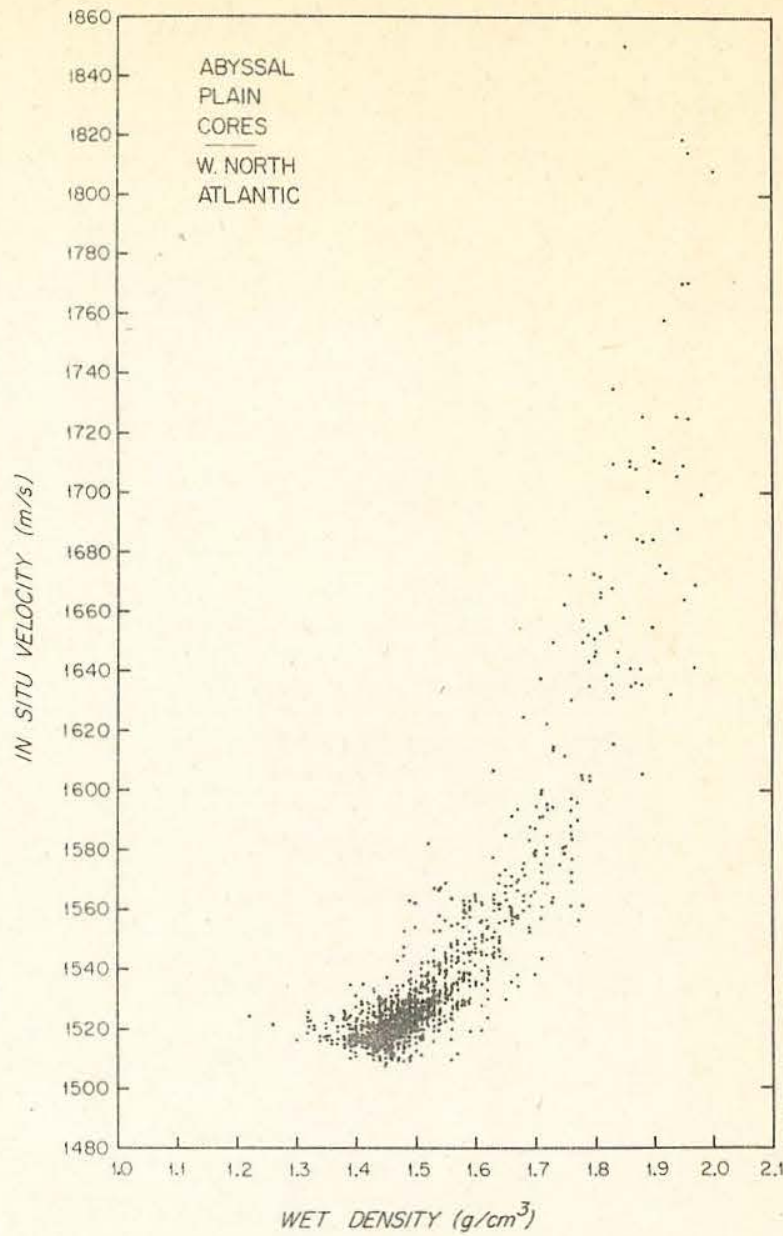

FIG. 13. Plot of in-situ velocity versus wet bulk density for sediment samples from Hatteras and Nares Abyssal Plain cores.

Hatteras, represent strongly reflective seabed and have the greatest variance in properties. Core RC2027, recovered off the mouth of Hatteras Canyon, contains a thick, graded sand bed and consequently exhibits the highest average velocity and wet bulk density of all the cores (Fig. 2). Core RC20-26, recovered near the southwest margin of the canyon mouth, contains numerous, thinner graded sand beds of high velocity and density (Fig. 3). However, in average velocity and bulk properties, this core is virtually identical to core RC20-21 recovered from the southern Hatteras Abyssal Plain much farther from the source area; as noted earlier, the similar average properties result because RC20-21 contains more numerous, but finer grainsize, graded silt beds (Fig. 4).

Cores from three areas, the northeast Hatteras Abyssal Plain, the central Nares Abyssal Plain, and the Kane Fracture Valley, represent less reflective seabed environments (Table I). Whole-core properties are virtually identical in all these cores although detailed sedimentary structures and depositional environments vary markedly (Figs. $5-8$ ). Core RC $20-28$ from the northeast Hatteras Abyssal Plain is the only core with megascopically graded silt beds and these high-velocity beds are fairly thick and widely spaced. Proceeding toward more "distal" environments in cores RC20-18 


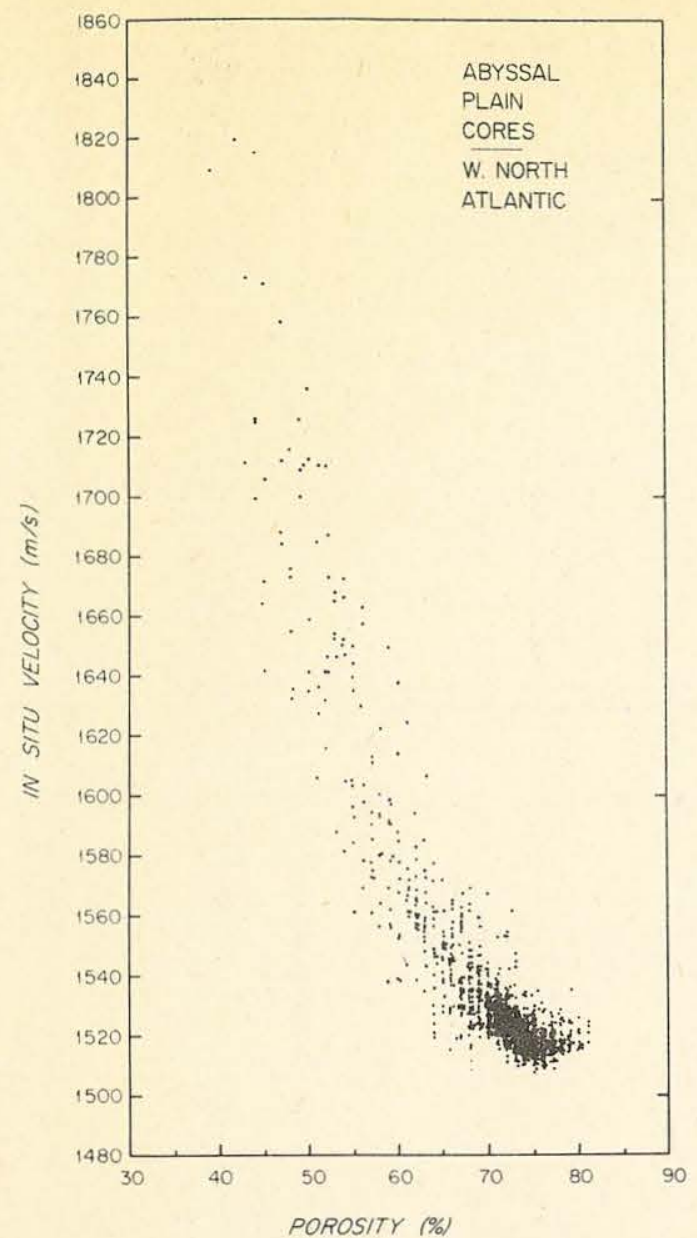

FIG. 14. Plot of in-situ velocity versus porosity for sediment samples from Hatteras and Nares Abyssal Plain cores.

and 19 (central Nares plain; Figs. 6 and 7) and core RC19-37 (Kane Fracture Valley; Fig. 8), the silt beds become thinner and finer grained (and thus have lower velocities), and they are more numerous. It is puzzling that the "distal" sediments in the Kane Fracture Valley contain several thick silt beds. They probably are not derived from a local source because similar beds do not occur in the adjacent Nares Deep Fracture Valley; they may represent nearly total deposition from turbid flows trapped in the virtual cul-de-sac of the Kane Fracture Valley.

Cores from the southwest Nares Abyssal Plain (e.g. RC19-20; Fig. 9) and Nares Deep Fracture Valley (RC19-33; Fig. 10) contain substantially fewer or no silt beds and thus form a group whose whole-core properties describe a still less reflective seabed environment. It is notable that sediments from the more "proximal" southwestern edge of the Nares Abyssal Plain (RC19-20, Fig. 9) have fewer high-velocity silt layers and define a less reflective seabed than the sediments from the more "distal" central Nares Abyssal Plain and Kane Fracture Valley. This probably occurs because these sediments were deposited farther from the axis of turbidity-current pathways impinging on the Nares Abyssal Plain.

The cores from the eastern Nares Abyssal Plain contain no silt beds and rarely exhibit silt partings. They

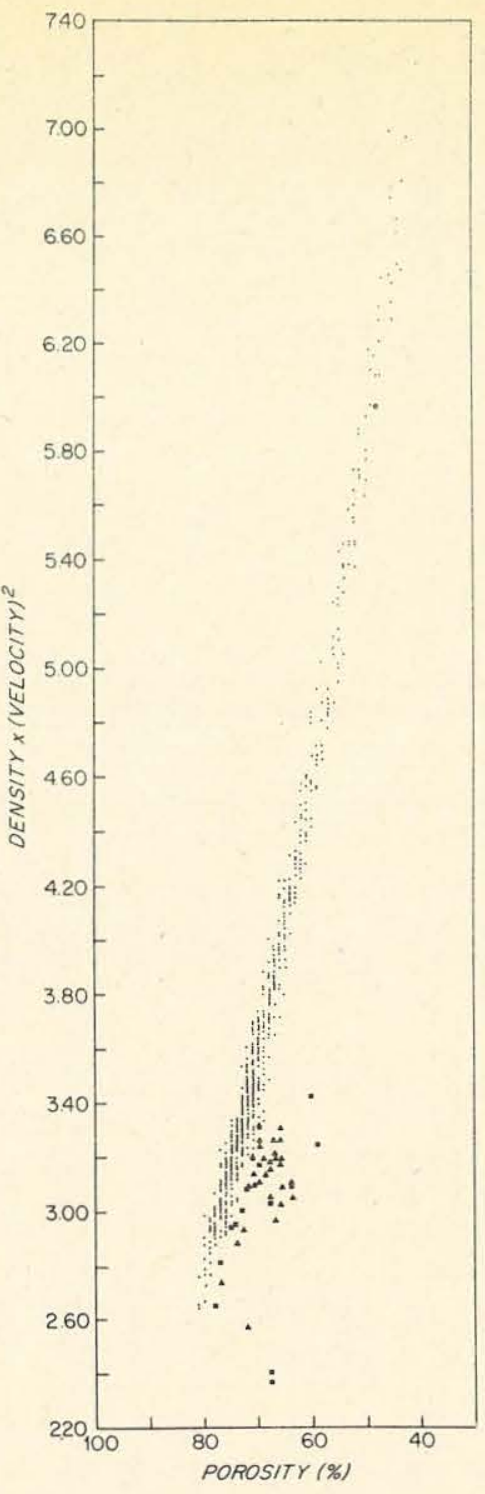

FIG. 15. Plot of density $\times(\text { in-situ velocity })^{2}$ versus porcsity for sediments from Hatteras and Nares Abyssal Plain cores. Bold symbols show samples with grain densities $\leqslant 2.50 \mathrm{~g} / \mathrm{cm}^{3}$ : triangles-from cores $\mathrm{RC} 19-27,28$, and 29; squares-from cores RC19-20, 32, 33, 36, 37.

form a group whose whole-core properties describe the least reflective seabed observed in this study.

The whole-core properties show marked gradations through the sequence of acoustic environments just described (Table I). Whole-core velocities range from $1636 \mathrm{~m} / \mathrm{s}$ in the strongly reflective seabed of the north central Hatteras Abyssal Plain to as low as $1521 \mathrm{~m} / \mathrm{s}$ in the least reflective seabed of the easternmost Nares Abyssal Plain. The same pattern is observed in distribution of maximum velocity on a sample-by-sample basis (Fig. 12). In the regions with a more reflective seabed, velocities are distributed over broad ranges, and they progress to very narrowly defined ranges in less reflective seabed areas. Velocity gradient in these cores does not show any marked gradation (Table I), but the significance of such gradients, which were calculated in the presence of numerous high-velocity beds, may be questionable.

A gradational decrease in wet-bulk density toward the less reflective seabed environments is observed in the whole-core analyses (Table I) and also occurs in distribution of maximum density on a sample-by-sample basis. This decrease relates to the progression toward 


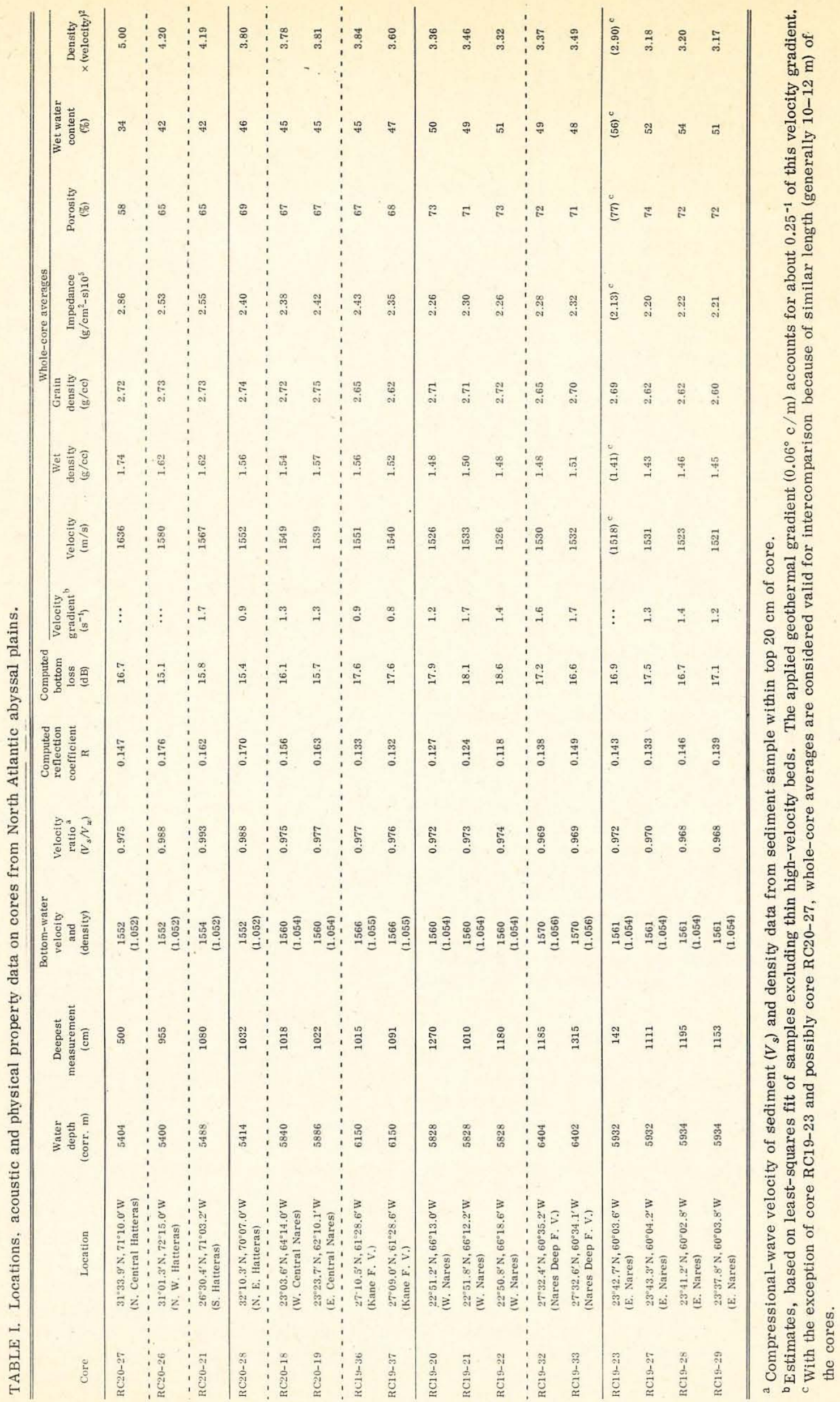


finer grain sizes and is accompanied by complementary increases in porosity and water content. The decrease in whole-core grain density from $2.72-2.75 \mathrm{~g} / \mathrm{cm}^{3}$ to about $2.60-2.62 \mathrm{~g} / \mathrm{cm}^{3}$ (Table I). The decrease in grain density probably reflects decreased competence of turbidity currents to transport the denser particles to more "distal" environments.

\section{3. "Seafloor" acoustic character (surface analyses)}

Acoustic properties determined on the basis of samples from the upper $20 \mathrm{~cm}$ of the sediment column ("seafloor" properties) are listed in Table I and plotted in Fig. 16 in the same order as the whole-core properties discussed above. Although gradations occur from the strongly reflective to the weakly reflective seabed regions, they are much less well defined than the trends in whole-core properties. If the cores were reordered to produce a uniform gradation in seafloor acoustic properties, the organization would make little sense in terms of the overall depositional or acoustic environment. Therefore, as noted earlier, the use only of seafloor properties may be misleading when discussing acoustic environments at frequencies where subbottom penetration of tens of meters and more is achieved.

The ratio of surface-sediment velocity to bottomwater velocity $\left(V_{s} / V_{w}\right)$ shows a general decrease toward less reflective seabed regions (Fig. 16), but significant exceptions occur in cores from the northern Hatteras Abyssal Plain. The surface sediments in core RC20-27, and possibly in RC20-26, are hemipelagic clays that bear little or no relation to the underlying, environmentally characteristic, graded turbidite sands.

The Rayleigh reflection coefficient

$$
R=\left(\rho_{s} V_{s}-\rho_{w} V_{w}\right) /\left(\rho_{s} V_{s}+\rho_{w} V_{w}\right),
$$

(where $\rho_{w}$ and $\rho_{s}$ are water and sediment density) shows a trend even less well defined than that of $V_{s} / V_{w}$. The
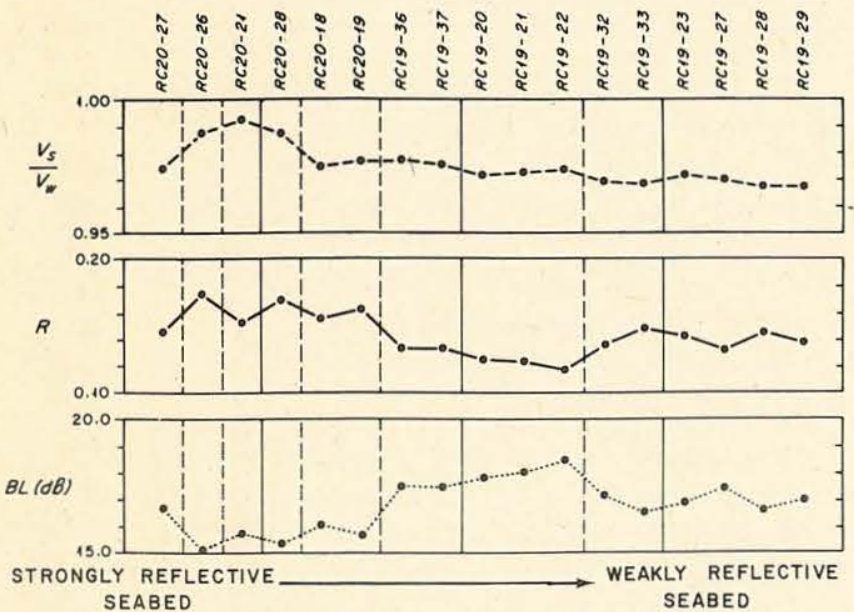

FIG. 16. Ratio of in-situ sediment velocity to bottom-water velocity (top), Rayleigh reflection coefficient computed from equation (6) (center), and computed bottom loss (lower) all for "seafloor" samples within $20 \mathrm{~cm}$ of the sediment surface; arranged as in Table I from areas of strongly reflective (left) to weakly reflective seabed. less reflective seabed environments of the Nares Deep Fracture Valley and eastern Nares Abyssal Plain have higher computed seafloor reflectivity than more "proximal" regions. The increased reflectivity relates directly to increased near-surface wet-bulk densities (e.g., Figs. 10 and 11) that could result from improved grain packing in these distal environments where slow, particle-by-particle pelagic deposition occurs.

Computed bottom loss, $(\mathrm{BL}=-20 \log R)$ shows a trend inverse to that of computed reflection coefficient but has the same complicating factors. Although bottom loss is relatively low $(15-16 \mathrm{~dB})$ in much of the region of strongly reflective seabed, the value of $16.7 \mathrm{~dB}$ in hemipelagic clays overlying graded sands in core RC20-27 is not significantly different from the 16.7$17.5 \mathrm{~dB}$ bottom loss in the regions of weakly reflective seabed.

It is reasonable to conclude that "seafloor" acoustic properties are not a wholly valid method of predicting acoustic environments of abyssal plain areas. Such "seafloor" properties may differ significantly from the properties of immediately underlying sediments because pelagic, hemipelagic, and turbidite deposition occur intermittently on abyssal plains and each process produces a markedly different acoustic signature.

\section{F. Correlation to $3.5-\mathrm{kHz}$ echo character}

The gradation in acoustic character observed in the whole-core properties also is observed in $3.5-\mathrm{kHz}$ echo character. The gradation is present but is less well defined in $12-\mathrm{kHz}$ records because of more limited signal penetration, and $12-\mathrm{kHz}$ records therefore are not considered further here. Because all our $3.5-\mathrm{kHz}$ records are analog recordings acquired under varying weather and instrumental conditions, their correlation to wholecore acoustic properties is purely qualitative. Four kinds of echo variation tend to characterize the acoustic nature of abyssal plain sediments: (1) Degree of backscattering, (2) prolongation of reflected signal, (3) reflector resolution, and (4) signal penetration.

In areas of strongly reflective seabed (Figs. 2-4), $3.5-\mathrm{kHz}$ records usually exhibit a great deal of random subbottom noise or "acoustic haze"; this backscattering contrasts markedly with the clean subbottom signals in weakly reflective seabed environments (Fig. 11). The backscattering is developed only where thicker, usually graded sand and silt beds were recovered in piston cores; it is likely that bedforms with spacing on the order of a wavelength (about $40 \mathrm{~cm}$ at $3.5 \mathrm{kHz}$ ) in these thicker turbidites are responsible for the signal scattering. If bedforms are associated with thinner turbidites in the more acoustically subdued environments, they may have such small spacing that similar signal scattering is reduced or precluded.

Prolongation of the echo return (i.e., prolonged echo ${ }^{27}$ ) also is characteristic of strongly reflective as opposed to weakly reflective seabed environments (compare Figs. 3 and 11). Damuth ${ }^{27}$ showed that increased echo prolongation occurs with increases in the amount of 
coarse material and the thickness of coarse beds in piston cores, and this observation also applies in the present study. However, it is also true that numerous, closely spaced thin silt beds can give a prolonged echo (Fig. 8). The echo prolongation therefore probably is due to two separate effects: (1) Increased backscattering from thick, coarse beds as noted above, and (2) complex signal interference and "ringing" caused by reflections from numerous closely spaced beds. Compared to regions of strongly reflective seabed with thick coarse beds, the occurrence of numerous thin and closely spaced beds can be distinguished by a reduction in random backscattering, increased definition of individual reflectors (where resolved), and generally increased subbottom penetration (compare Figs. 2 and 8).

Reflector resolution generally improves from strongly reflective seabed to weakly reflective seabed environments (Figs. 2-11), primarily because of reduced signal scattering. A marked improvement occurs in regions of weakly reflective seabed because closely spaced coarse beds are rare and signal interference therefore is reduced. It must be recognized that higher recording gains usually are used in these regions, and reflections generated at smaller impedance contrasts therefore can be resolved (Fig. 11). The same recording gain in an area of strongly reflective seabed probably would result in signal saturation for all subbottom data. This gain-dependent recognition of reflecting interfaces generally precludes using the number or spacing of reflectors as an index to the acoustic nature of the sediments.

Signal penetration also improves from strongly reflective to weakly reflective seabed regions (Figs. 211). However, signal penetration again is strongly influenced by recording gain (Fig. 10), as well as by other system and weather conditions, and signal penetration alone is not a reliable indicator of the acoustic environment.

By itself none of the above variations in echo character is totally satisfactory in defining the acoustic environment. Taken together, however, these factors are qualitatively useful in predicting the frequency of occurrence and thickness of coarser beds and thus the gross velocity and physical properties of the seabed.

No attempt has been made in this discussion to correlate individual impedance contrasts observed in cores with reflectors in the $3.5-\mathrm{kHz}$ records. Some correlations are obvious (e.g., the impedance break and reflector near $6 \mathrm{~m}$ subbottom, Fig. 5), but in most instances beds of contrasting impedance are so closely spaced that signal interference either totally masks reflectors (Fig. 8) or "constructs" a reflector at a position inappropriate to the known impedance break (Figs. 7,9). Mayer ${ }^{12}$ has provided an elegant demonstration of the significance of such interference effects in records of this frequency range $(2,4$, and 6 $\mathrm{kHz}$ ).

\section{SUMMARY AND CONCLUSIONS}

Measurements of compressional-wave velocity and bulk physical properties to depths of $10-12 \mathrm{~m}$ in seventeen piston cores recovered from western North Atlantic abyssal plains show the following:

(1) The general acoustic character of abyssal plain sediments is strongly related to the frequency of occurrence, mean grain size, and thickness of high-velocity beds beneath the seafloor. Thick turbiditic sand beds characterize strongly reflective seabed areas and fine-grained clay turbidites create weakly reflective seabed environments. Distribution of coarse beds probably is controlled by a combination of factors: Distance from source, position relative to turbidity-current flow axes, regional and local basin geometry, and seafloor slope. Thus seabed acoustic character is not simply a function of proximity to source areas, and weakly reflective seabed environments often occur in more "proximal" areas than do more strongly reflective seabed environments.

(2) The acoustic character of abyssal plains is most successfully predicted by using whole-core analyses that average the entire range of lithofacies and properties at a given location. Because deposition of turbidites is sporadic and alternates with pelagic or hemipelagic deposition, the lithologic and acoustic nature of "seafloor" sediments (within the upper few tens of centimeters of the sediment column) is laterally highly variable and often much different from immediately underlying sediments. Because acoustic signals with frequencies of a few kilohertz or less penetrate tens of meters and more into the seabed, use of "seafloor" properties in predicting acoustic character of abyssal plains therefore can be misleading. Although computation of reflection coefficients and bottom losses are more complex when subbottom layers are considered, such computations probably predict the acoustic environment more accurately than the use simply of "seafloor" properties. Cole ${ }^{28}$ and Hastrup ${ }^{29}$ have discussed approaches to the problem of considering subbottom layers.

(3) Qualitatively, 3.5-kHz echo character across abyssal-plain regions correlates rather well with whole-core properties. Strongly reflective seabed areas with thick graded sand layers show maximum acoustic backscatter and echo prolongation, and minimal signal penetration and reflector definition. These relations are reversed along a gradational trend to weakly reflective seabed regions where no high-velocity layers are present.

(4) Relations previously documented between compressional-wave velocity and density, porosity, and mean grain size are confirmed by this study. However, restriction of in-situ velocity measurements reported here to only abyssal-plain samples considerably reduces scatter in plots of these data. The samples reported here are representative of most environments in the Hatteras and Nares Abyssal Plains, and our data on physical properties and in-situ velocities of sediments therefore form a sound basis for prediction of the 
acoustic and elastic behavior of the seabed in these regions.

\section{ACKNOWLEDGMENTS}

Data collection and much of the analysis were supported by ONR Contract N00014-75-C-0210 to LamontDoherty Geological Observatory (Columbia University) during my residence there. At Woods Hole, support by ONR Contract N00014-79-C-0071, NR083-004 is gratefully acknowledged. I am indebted to Robert W. Embley who was responsible for data collection on seven of the cores and who has provided valuable discussion throughout the study. I thank M. Delach, S. McNutt, M. Sundvik, G. Mountain, P. Hoose, J. Kostecki, and $\mathrm{K}$. Brockett for technical assistance and Captain P. Olander and the crew of the R/V CONRAD for their support in seagoing operations. Reviews of this paper by E. T. Bunce, J. I. Ewing, and D. A. Johnson are appreciated.

${ }^{1}$ J. E. Nafe and C. L. Drake, "Physical Properties of Marine Sediments," in The Sea, edited by M. N. Hill (Wiley, New York, 1963), Vol. 3, pp. 794-815.

${ }^{2}$ R. E. Houtz and J. I. Ewing, "Detailed Sedimentary Velocities from Seismic Reflection Profiles in the Western North Atlantic," J. Geophys. Res. 68, 5233-5258 (1963).

${ }^{3}$ X. LePichon, J. I. Ewing, and R. E. Houtz, "Deep-Sea Sediment Velocity Determination Made While Reflection Profiling," J. Geophys. Res. 73, 2597-2614 (1968).

${ }^{4}$ G. M. Bryan, "Sonobuoy Measurements in Thin Layers," in Physics of Sound in Marine Sediments, edited by L. Hampton (Plenum, New York, 1974), pp. 119-130.

${ }^{5}$ E. L. Hamilton, H. P. Bucker, D. L. Keir, and J. A. Whitney, "Velocities of Compressional and Shear Waves in Marine Sediments Determined In Situ from a Research Submersible," J. Geophys. Res. 75, 4039-4049 (1970).

${ }^{6}$ E. L. Hamilton, "Sound Velocity and Related Properties of Marine Sediments, North Pacific," J. Geophys. Res. 75, 4423-4446 (1970).

${ }^{7}$ E. L. Hamilton, "Prediction of In-Situ Acoustic and Elastic Properties of Marine Sediments," Geophysics 36, 266-284 (1971).

${ }^{8}$ E. L. Hamilton, "Elastic Properties of Marine Sediments," J. Geophys. Res. 76, 579-604 (1971).

${ }^{9}$ B. E. Tucholke and D. J. Shirley, "Comparison of Laboratory and In-Situ Compressional-Wave Velocity Measurements on Sediment Cores from the Western North Atlantic, "J. Geophys. Res. 84, 687-695 (1979).

${ }^{10}$ R. W. Embley, "Studies of Deep-Sea Sedimentation Processes Using High Frequency Seismic Data," Ph.D. thesis, Columbia University, New York (1975).

${ }^{11}$ R. W. Embley and D. A. Johnson, "Acoustic Stratigraphy and Biostratigraphy of Neogene Carbonate Horizons in the North
Equatorial Pacific," J. Geophys. Res. (in press).

${ }^{12}$ L. Mayer, "The Origin of Fine Scale Acoustic Stratigraphy in Deep-Sea Carbonates, " J. Geophys. Res. 84, 6177-6184 (1979).

${ }^{13}$ B. C. Schreiber, "Sound Velocity in Deep Sea Sediments," J. Geophys. Res. 73, 1259-1268 (1968).

${ }^{14}$ D. R. Horn, M. Ewing, B. M. Horn, and M. N. Delach, "A Prediction of Sonic Properties of Deep-Sea Cores, Hatteras Abyssal Plain and Environs," Lamont-Doherty Geol. Obs. Tech. Rept. No. 1, CU-1-69 Navships N0002.4-69-C-1184 (1969).

${ }^{15}$ D. R. Horn, M. Ewing, M. N. Delach, and B. M. Horn, "A Prediction of Sonic Properties of Deep-Sea Cores, Sohm Abyssal Plain and Environs," Lamont-Doherty Geol. Obs. Tech. Rept. No. 2, CU-2-69 Navships N00024-69-C-1184 (1969).

${ }^{16}$ A. H. Bouma, Sedimentology of Some Flysch Deposits, a Graphic Approach to Facies Interpretation, (Elsevier, New York, 1962).

${ }^{17}$ C. D. Hollister, "Sediment Distribution and Deep Circulation in the Western North Atlantic," Ph.D. thesis, Columbia University, New York (1967).

${ }^{18}$ W. H. Ward, S. G. Samuels, and M. E. Butler, "Further Studies of the Properties of London Clay," Geotechnique 9, 33-58 (1959).

${ }^{19}$ U. S. Naval Oceanographic Office, Tables of Sound Speed in Seawater, Navoceano SP58, Washington, DC, 47 pp. (1962).

${ }^{20}$ M. G. Langseth, Jr., and R. P. Von Herzen, "Heat Flow Through the Floor of theWorld Oceans," in The Sea, edited by A. E. Maxwell (Wiley, New York, 1970), Vol. 4, Part 1, pp. 299-352.

${ }^{21}$ D. R. Horn, M. Ewing, B. M. Horn, and M. N. Delach, "Turbidites of the Hatteras and Sohm Abyssal Plains," Marine Geol. 11, 287-323 (1971).

${ }^{22}$ W. J. Cleary, O. H. Pilkey, H. A. Curran, and W. J. Neal, "Patterns of Turbidite Sedimentation on a Trailing Plate Margin: Hatteras Abyssal Plain, Western North Atlantic Ocean," Tenth Int'l. Congr. on Sedimentology, Jerusalem, Abstracts 1, 126-127 (1978).

${ }^{23}$ T. H. Shipley, "Sedimentation and Echo Characteristics in the Abyssal Hills of the West-Central North Atlantic," Geol. Soc. Am. Bull. 89, 397-408 (1978).

${ }^{24}$ D. R. Horn, B. M. Horn, and M. N. Delach, "Correlation Between Acoustical and Other Physical Properties of Deep-Sea Cores," J. Geophys. Res. 73, 1939-1957 (1968).

${ }^{25}$ F. Gassmann, "Uber die Elastizitat Poroser Medien," Vierteljahrsschrift Gesellschaft in Zurich 96, 1-23 (1951).

${ }^{26}$ A. B. Wood, A Textbook of Sound (G. Bell, London, 1941).

${ }^{27}$ J. E. Damuth, "Echo Character of the Western Equatorial Atlantic Floor and its Relationship to the Dispersal and Distribution of Terrigenous Sediments," Marine Geol. 18, 17-45 (1975).

${ }^{28}$ B. F. Cole, "Marine Sediment Attenuation and Ocean- BottomReflected Sound," J. Acoust. Soc. Am. 38, 291-297 (1965).

${ }^{29}$ O. F. Hastrup, "Digital Analysis of Acoustic Reflectivity in the Tyrrhenian Abyssal Plain," J. Acoust. Soc. Am. 47, 181190 (1970). 



\section{MANDATORY DISTRIBUTION LIST}

FOR UNCLASSIFIED TECHNICAL REPORTS, REPRINTS, AND FINAL REPORTS

PUBLISHED BY OCEANOGRAPHIC CONTRACTORS

OF THE OCEAN SCIENCE AND TECHNOLOGY DIVISION

OF THE OFFICE OF NAVAL RESEARCH

(REVISED NOVEMBER 1978)

1 Deputy Under Secretary of Defense (Research and Advanced Technology) Military Assistant for Environmental Science Room 30129

Washington, D.C. 20301

Office of Naval Research 800 North Quincy Street

Arlington, VA 22217

3 ATTN: Code 483

ATTN: Code 460

ATTN : 102B

1 CDR J. C. Harlett, (USN)

ONR Representative

Woods Hole Oceanographic Inst.

Woods Hole, MA 02543

Commanding officer

Naval Research Laboratory

Washington, D.C. 20375

6 ATTN: Library, Code 2627
12 Defense Documentation Center Cameron Station

Alexandria, VA 22314

ATTN: DCA

Commander

Naval Oceanographic Office NSTL Station

Bay St. Louis, MS 39522

1 ATTN: Code 8100

1 ATTN: Code 6000

1 ATTN: Code 3300

1 NODC/NOAA

Code 0781

Wiscons in Avenue, N.W.

Washington, D.C. 20235 
UNCLASSIFIED $6 / 81$

SECURITY CLASSIFICATION OF THIS PAGE (When Dafe Entered)

\begin{tabular}{|c|c|}
\hline REPORT DOCUMENTATION PAGE & $\begin{array}{l}\text { READ INSTRUCTIONS } \\
\text { BEFORE COMPLETING FORM }\end{array}$ \\
\hline 2. GOVT ACCESSION.NC & 3. RECIPIEN T'S CATALOG NUMBER \\
\hline \multirow{2}{*}{$\begin{array}{l}\text { 4. TITLE (and Subtitlo) } \\
\text { ACOUSTIC ENVIRONMENT OF THE HATTERAS ANO NARES } \\
\text { ABYSSAL PLAINS, WESTERN NORTH ATLANTIC OCEAN, } \\
\text { DETERMINED FROM VELOCITIES AND PHYSICAL PROPER- } \\
\text { TIES OF SEDIMENT CORES } \\
\text { 7. AUTHOR(o) }\end{array}$} & $\begin{array}{l}\text { S. TYPE OF REPORT A PERIOD COVERED } \\
\text { Technical }\end{array}$ \\
\hline & $\begin{array}{l}\text { 6. PERFORMING ORG. REPORT NUMAER } \\
\text { WHOI CONT. \#4547 }\end{array}$ \\
\hline $\begin{array}{l}\text { 7. AUTHOR(o) } \\
\text { Brian E. Tucholke }\end{array}$ & $\begin{array}{l}\text { 9. CONTRACT OR GRANT NUMGER(O) } \\
\text { NO0014-75-C-0210 } \\
\text { *N00014-79-C-0071; }\end{array}$ \\
\hline $\begin{array}{l}\text { 9. PERFORMING ORGANIZATION NAME AND ADDRESS } \\
\text { Woods Hole Oceanographic Institution } \\
\text { Woods Hole, Massachusetts } 02543\end{array}$ & $\begin{array}{l}\text { 10. PROGRAM ELEMENT, PROJECT, TASK } \\
\text { AREA Q WORK UNHT NUMERS } \\
\text { *NR } 083-004\end{array}$ \\
\hline $\begin{array}{l}\text { 11. CON TROLLIING OFFICE NAME AND ADORESS } \\
\text { NORDA/National Space Technology Laboratory } \\
\text { Bay. St. Louis, MS } 39529\end{array}$ & $\begin{array}{l}\text { 12. AEPONT DATE } \\
\text { June } 1981 \\
\text { 13. NIIMBER OF PAGES }\end{array}$ \\
\hline 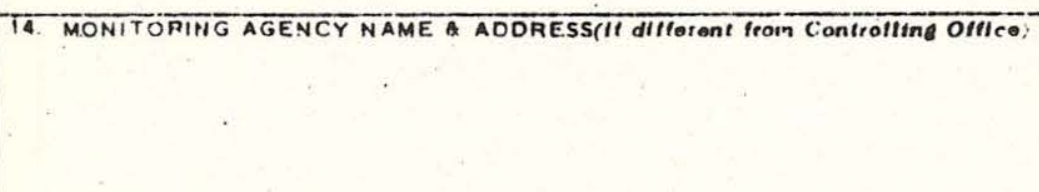 & 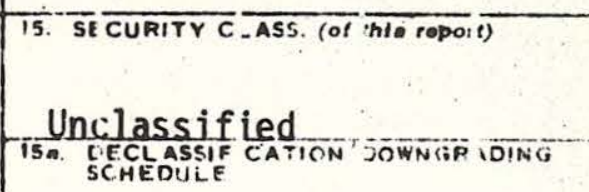 \\
\hline
\end{tabular}

Approved for public release; distribution unlimited.

17. OISTRIBUTION STATEMENT iof the ototract onfored in Bioch 20. "I difforent from. Repor)

18. SUPPLEMENTARY NOTES

Reprinted from: J. Acoust. Soc. Am. 68(5): 1376-1390 (Nov. 1980).

19. KEY WORDS (Continue on reveree elde if noceeceary and ldentlly by block number)

1. Sediment velocities

2. Sediment physical properties

3. Atlantic Abyssal Plains

20. ABSTRACT (Continue on reverve alde If neceseery end ldentlfy by block number)

See back. 
Seventeen piston cores up to $13 \mathrm{~m}$ long were recovered from representative acoustic and lithologic environments of the Hatteras and Nares Abyssal Plains in the western North Atlantic.Compressional-wave velocities (corrected to in situ conditions) and bulk physical properties measured on the cores are used to characterize the acoustic framework of these areas. For correlation with conventional seismic data, whole-core averages of properties are a better index to the acoustic nature of abyssal plain sediments than properties of the upper few centimeters of the seafloor because (1) strong changes in 1ithofacies (and acoustic properties) occur over the depth scales of tens of centimeters to meters in the sediment column, and (2) conventional seismic frequencies of $3.5 \mathrm{kHz}$ or less sample these variations to subbottom depths of tens of meters and more. Whole-core properties are a function of the thickness and distribution of high-velocity silt and sand layers in the core; they vary in a complex fashion with proximity to the source of turbidity currents, distance from axial paths of turbidity-current flows, local and regional basin geometry, and seafloor slope. This strongly reflective seabed regions with numerous high-velocity layers are not restricted simply to near-source areas nor are weakly reflective seabed regions (clay sediments only) limited to "distal" areas. Whole-core properties show a good qualitative correlation to variations in $3.5-\mathrm{kHz}$ reflection profiles, and $3.5-\mathrm{kHz}$ acho character therefore provides a useful means of mapping general acoustic properties over large regions of abyssal plains. 


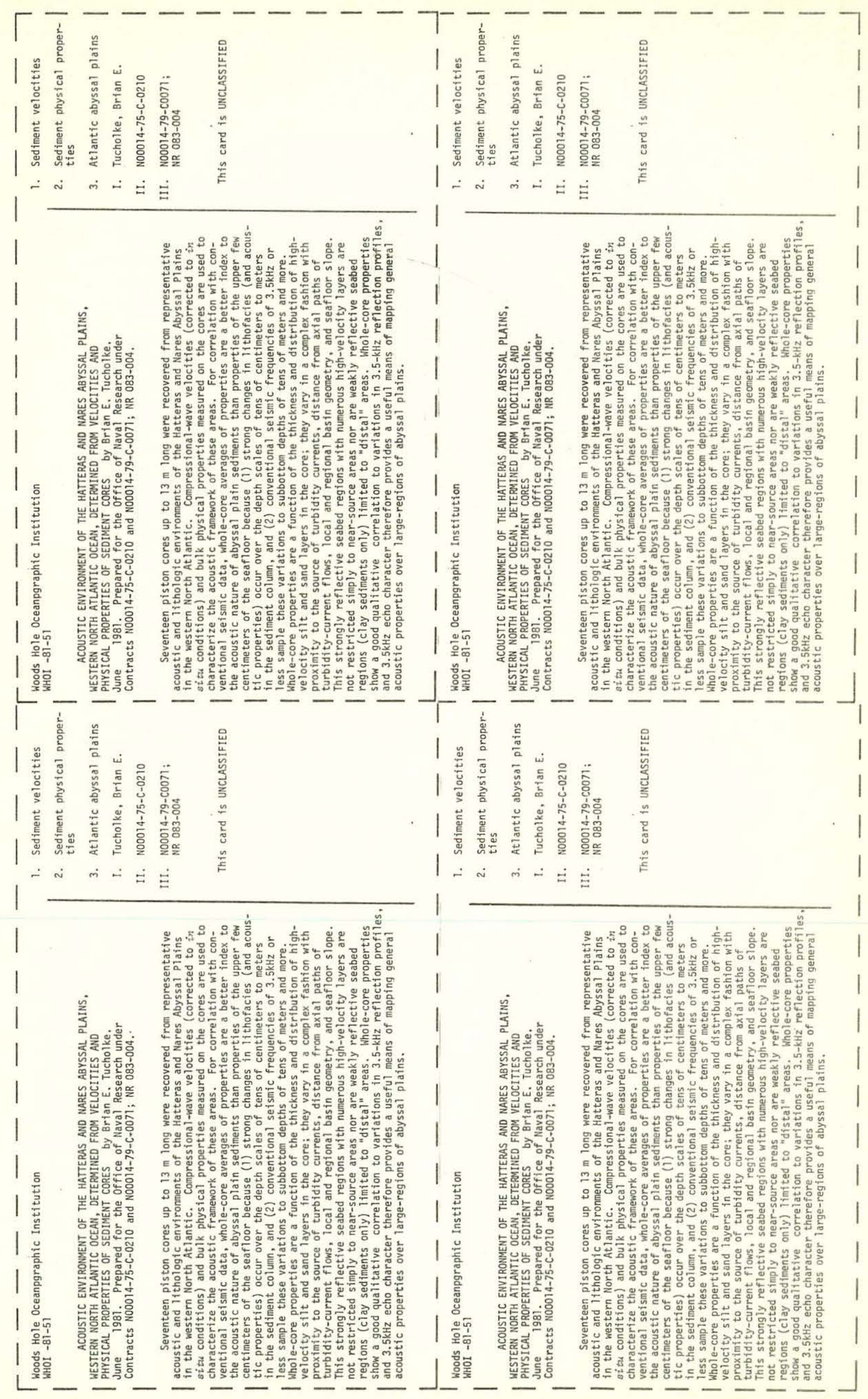

